\title{
Use of Gibberellic Acid to Increase the Salt Tolerance of Leaf Lettuce and Rocket Grown in a Floating System
}

\author{
Filippo Vetrano, Alessandra Moncada * and Alessandro Miceli *(D) \\ Dipartimento Scienze Agrarie, Alimentari e Forestali, Università di Palermo, Viale delle Scienze 4, \\ 90128 Palermo, Italy; filippo.vetrano@unipa.it \\ * Correspondence: alessandra.moncada@unipa.it (A.M.); alessandro.miceli@unipa.it (A.M.); \\ Tel.: +39-091-23862219 (Alessandro Miceli)
}

Received: 6 March 2020; Accepted: 27 March 2020; Published: 2 April 2020

check for updates

\begin{abstract}
Hydroponics need water of good quality to prepare a balanced nutrient solution that could allow plants to reach their maximum yield potential. The rising difficulties in finding water with good quality have led to the compelling necessity of identifying sustainable ways to use saline water, limiting its negative effect on crop yield and quality. The exogenous supplementation of plant growth regulators, such as gibberellic acid $\left(\mathrm{GA}_{3}\right)$, can be effective in increasing plant growth and vigor, thus helping plants to better cope with salt stress. The aim of this study was to evaluate the feasibility to increase the salt tolerance of leaf lettuce and rocket grown in a floating system by adding $\mathrm{GA}_{3}$ $\left(10^{-6} \mathrm{M}\right)$ to mineral nutrient solutions (MNS) with increasing salinity $(0,10$, and $20 \mathrm{mM} \mathrm{NaCl})$. Leaf lettuce and rocket plants suffered a significant reduction of growth and yield, determined by the reduction of biomass, leaf number, and leaf area, even with moderate salt stress $(10 \mathrm{mM} \mathrm{NaCl})$. The supplementation of exogenous $\mathrm{GA}_{3}$ through the MNS allowed plants to substantially counterbalance salt stress by enhancing various morphological and physiological traits, such as biomass accumulation, leaf expansion, stomatal conductance and water and nitrogen use efficiency. The effects of salt stress and $\mathrm{GA}_{3}$ treatment varied according to the species, thus indicating that this interaction may improve salt tolerance by activating different adaptation systems.
\end{abstract}

Keywords: saline water; leafy vegetables; Lactuca sativa L. var. Crispa; Eruca sativa L.; hydroponics; $\mathrm{GA}_{3}$; ascorbic acid; nitrate

\section{Introduction}

Currently, one of the major challenges of agricultural research is to meet the increasing food demand while protecting natural resources and improving environmental quality. Nevertheless, agricultural sustainability is threatened by the burgeoning human population and decreasing availability of land for cultivation. The most important factor causing the reduction in cultivated lands is the accumulation of soluble salts [1]. Soil and water salinity represents one of the major environmental stresses and determines severe reductions in crop productivity and quality [1,2]. Salinity negatively influences the germination, growth, physiology, and productivity of crop plants. These negative effects may be triggered by ionic and osmotic stresses, ion toxicity, oxidative damage, and membrane instability and permeability [3-6]; salt stress can also affect plant physiology, determining an increased respiration rate, changes in $\mathrm{C}$ and $\mathrm{N}$ metabolism, modification of mineral uptake and distribution, altered chlorophyll biosynthesis, and inefficiency of photosynthesis [7,8]. All these effects result in lowered yield and quality and reduced economic productivity of crops. Vegetable crops have a cash value usually higher than field crops, thus the salt tolerance of vegetable species is important for adequate fulfillment of 
vegetable demands and to limit the economic effects of salt stress on vegetable growers. Moreover, the high demand for water of vegetable crops, condensed in short production periods, increases their salinity problems [9].

Soilless cultivation systems (or hydroponics) have been adopted for many vegetable crops to overcome soil salinity and other abiotic and biotic stresses [10-12] and to increase yield and quality [11,13-15]. The quality of the water is of paramount importance in the hydroponic cultivation systems in which it is used to prepare nutrient solutions by adding mineral fertilizers that increase its electrical conductivity (EC). Hence, the availability of water with a high salt concentration leads to a nutrient solution with an EC level that trespasses the tolerance level of many vegetable crops [9]. The majority of high salinity irrigation water occurs in areas located along the sea, especially in Mediterranean areas with intensive agriculture, and in the hot seasons because the intensive use of underground water increases seawater infiltration in the groundwater [9].

The rising limitations in water quality and availability are increasing the attention in improving the efficiency of water use and enhancing crop tolerance to these stresses. Recently, the mechanisms of salt tolerance in plants has become the aim of many investigations [16,17], revealing that the response and adaptation of plants to salinity take place through the activation of stress response mechanisms, which control the ionic/hydraulic re-equilibrium and mediate the detoxification of reactive oxygen species, and the modulation of cell growth or cell division [18]. These mechanisms are mostly under hormonal control, and the adverse effect of salinity on seed germination and plant growth has been related to modifications of the endogenous levels of phytohormones. In fact, Wang et al. [19] found that salinity may determine an increase of abscisic acid (ABA) and jasmonic acid (JA) levels and a decrease of indole-3-acetic acid (IAA) and salicylic acid (SA) levels. This evidence suggested that the exogenous application of plant growth regulators (PGRs), such as auxins, gibberellins, or cytokinins, could have beneficial effects in mitigating the repressive effects of salt stress and also enhance germination, growth, development, yield, and quality [20-22].

Among these PGRs, gibberellins (GAs) are essential endogenous hormones produced by plants and fungi that control plant development by triggering several physiological mechanisms [23,24]. The response of plant tissue to the GA signal can be the modification in gene expression, plant physiology, and morphology [25]. These effects can also be determined by the application of exogenous gibberellins. Many investigations have focused the attention on the supplementation of gibberellic acid $\left(\mathrm{GA}_{3}\right)$, with the aim to improve plant growth and yield and to enhance tolerance to abiotic stresses (e.g., drought, heat, salinity). Exogenous supplementation through foliar spray of $\mathrm{GA}_{3}$ solutions at low concentrations has proved to determine positive effects on the growth, quality, and salt tolerance of vegetables cultivated in soil or in hydroponic cultivation systems [26-31]. Yet, studies on the effects of gibberellic acid application on leafy vegetables grown in hydroponics are rather scant. Miceli et al. [24,32] found that the supplementation of $10^{-6} \mathrm{M} \mathrm{GA}_{3}$ through the nutrient solution of hydroponically grown leaf lettuce and rocket can exert a significant effect on the yield, quality, and post-harvest life of these vegetables. Thus, the exogenous application of $\mathrm{GA}_{3}$ trough the nutrient solution could also affect the salt tolerance of leafy vegetables. Therefore, the aim of this study was to evaluate the feasibility of adding gibberellic acid $\left(10^{-6} \mathrm{M} \mathrm{GA}_{3}\right)$ to the mineral nutrient solution to increase the salt tolerance of leaf lettuce and rocket grown in a floating system.

\section{Materials and Methods}

\subsection{Leafy Vegetable Cultivation}

The experiment was conducted during spring in a greenhouse situated at the Department of Agricultural, Food, and Forest Sciences (SAAF - University of Palermo, Italy) ( $38^{\circ} 6^{\prime} 28^{\prime \prime} \mathrm{N} 13^{\circ} 21^{\prime} 3^{\prime \prime} \mathrm{E}$; altitude $49 \mathrm{~m}$ ). The leafy vegetables tested in this study were leaf lettuce (Lactuca sativa L. var. Crispa) and rocket (Eruca sativa L.). Six treatments derived from a factorial combination of three $\mathrm{NaCl}$ 
concentrations $(0,10$, and $20 \mathrm{mM} \mathrm{NaCl})$ and two $\mathrm{GA}_{3}$ concentrations $\left(0\right.$ and $10^{-6} \mathrm{M} \mathrm{GA}_{3}$ [24,32]; Gibrelex, Biolchim, Bologna, Italy) were tested for each species.

These species were cultivated in a hydroponic floating system using nutrient solutions prepared by adding to tap water (electrical conductivity-EC $0.48 \mathrm{mS} \mathrm{cm}^{-1}$; $\left.\mathrm{pH} 7.6\right) 4.5 \mathrm{mmol} \mathrm{L}^{-1}$ of $^{-2+}$, $2 \mathrm{mmol} \mathrm{L}^{-1}$ of $\mathrm{H}_{2} \mathrm{PO}_{4}^{-}, 1.25 \mathrm{mmol} \mathrm{L}^{-1}$ of $\mathrm{NH}_{4}^{+}, 1 \mathrm{mmol} \mathrm{L}^{-1}$ of $\mathrm{Mg}^{2+}, 19 \mathrm{mmol} \mathrm{L}^{-1}$ of $\mathrm{NO}_{3}^{-}, 11 \mathrm{mmol}$ $\mathrm{L}^{-1}$ of $\mathrm{K}^{+}, 1.1 \mathrm{mmol} \mathrm{L}{ }^{-1}$ of $\mathrm{SO}_{4}{ }^{2-}, 40 \mu \mathrm{mol} \mathrm{L}{ }^{-1}$ of Fe${ }^{3+}, 5 \mu \mathrm{mol} \mathrm{L}{ }^{-1}$ of $\mathrm{Mn}^{2+}, 4 \mu \mathrm{mol} \mathrm{L}{ }^{-1}$ of $\mathrm{Zn}^{2+}$, $30 \mu \mathrm{mol} \mathrm{L}{ }^{-1}$ of $\mathrm{BO}_{3}{ }^{3-}, 0.75 \mu \mathrm{mol} \mathrm{L}{ }^{-1}$ of $\mathrm{Cu}^{2+}$, and $0.50 \mu \mathrm{mol} \mathrm{L}^{-1}$ of Mo [33]. The nutrient solutions differed only in $\mathrm{GA}_{3}$ and $\mathrm{NaCl}$ concentration. The mineral nutrient solutions (MNSs) had pH 5.8 and an EC of 2.3, 3.4, and $4.4 \mathrm{mS} \mathrm{cm}^{-1}$ for 0,10 , and $20 \mathrm{mM} \mathrm{NaCl}$, respectively. Four different tubs $(100 \mathrm{~cm}$ long $\times 50 \mathrm{~cm}$ wide $\times 15 \mathrm{~cm}$ deep, containing $75 \mathrm{~L}$ ) were filled with each nutrient solution for each leafy vegetable. Seedlings of leaf lettuce (cv. 'Lattuga da Taglio a Foglia Liscia', Sementi Dotto-SDD SPA, Udine-Italy) and rocket (cv. 'Coltivata da orto', Sementi Dotto-SDD SPA, Udine-Italy) were obtained in polystyrene trays (160 holes) and transplanted (27 March) in drilled polystyrene panels (300 plants $\mathrm{m}^{-2}$ ) at the stage of 3-4 true leaves. The panels were then immediately placed to float in the tubes (Figure 1).
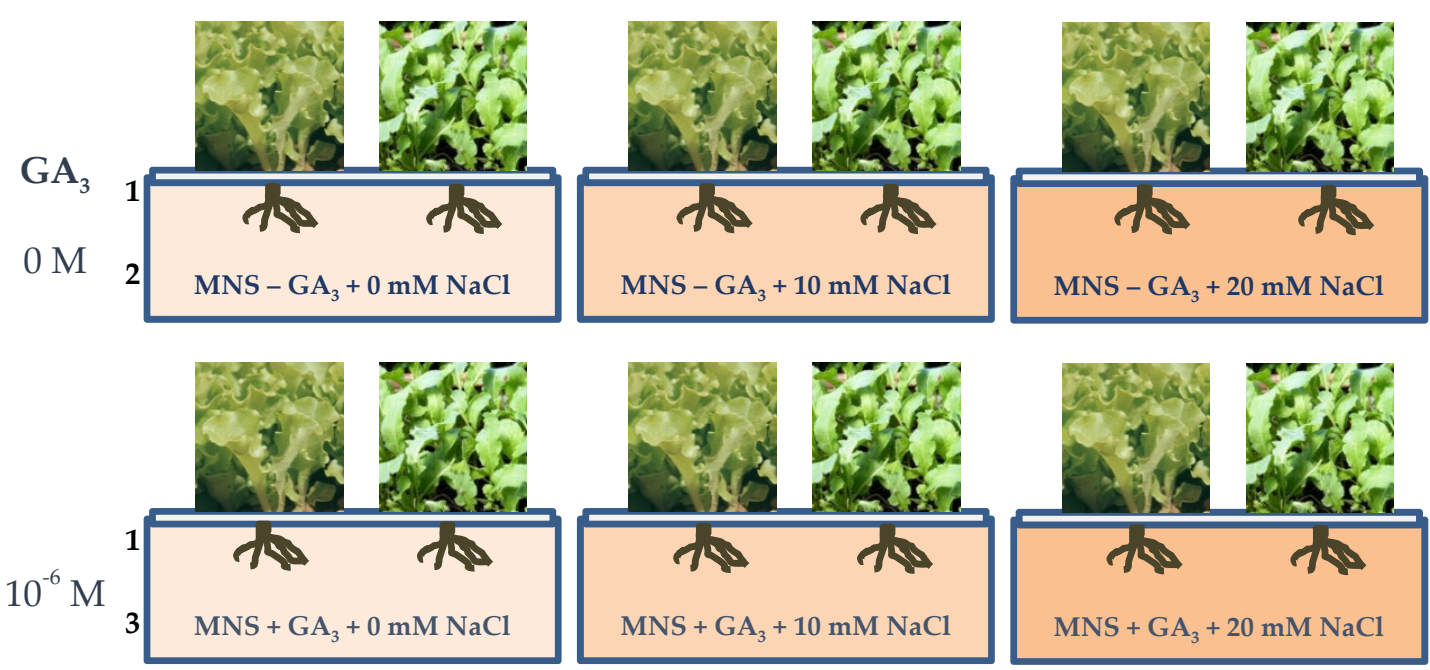

EC $2,3 \mathrm{mS} \mathrm{cm}^{-1}$

$3,4 \mathrm{mS} \mathrm{cm}^{-1}$

$4,4 \mathrm{mS} \mathrm{cm}^{-1}$

Figure 1. Graphical representation of the hydroponic floating system consisting of drilled polystyrene panels floating on mineral nutrient solutions with different combinations of gibberellic acid $\left(\mathrm{GA}_{3}\right)$ and $\mathrm{NaCl}$ levels. ${ }^{1}$ Drilled polystyrene panels $\left(300\right.$ plants $\mathrm{m}^{-2}$ ) floating on mineral nutrient solution (MNS); Tanks containing $75 \mathrm{~L}$ of MNS added with increasing concentrations of $\mathrm{NaCl}$ and ${ }^{2} 0 \mathrm{M} \mathrm{GA}_{3}$ or ${ }^{3} 10^{-6} \mathrm{M} \mathrm{GA}_{3}$.

Each treatment was composed of four replicated tubes for each combination of $\mathrm{GA}_{3}$ and $\mathrm{NaCl}$ (150 plants for each tube; 24 tubes for each species). The MNSs were not aerated during plant cultivation as leafy vegetables with fast growth and a short crop cycle do not need a high oxygen concentration in the nutrient solution [34]. The nutrient solutions were regularly monitored to evaluate water consumption and $\mathrm{EC}$ and $\mathrm{pH}$ changes. The tubes were replenished with new nutrient solutions, with the same $\mathrm{GA}_{3}$ and $\mathrm{NaCl}$ concentration, when the volume consumed overcame $20 \%$. The consumption of nutrient solution was assessed for each experimental treatment. The polystyrene panels completely covered the nutrient solutions in the tubes, thus the loss of water due to evaporation was minimal and was not considered. This allowed calculation of the water use efficiency (WUE) as WUE (g DW L ${ }^{-1}$ $\left.\mathrm{H}_{2} \mathrm{O}\right)=$ plant dry weight $(\mathrm{g}) / \mathrm{H}_{2} \mathrm{O}(\mathrm{L})$. At harvest, the nutrient solution in the tubs was analyzed to calculate the remaining amount of $\mathrm{N}^{-\mathrm{NH}_{4}}{ }^{+}$and $\mathrm{N}^{-\mathrm{NO}_{3}}{ }^{-}$(determined reflectometrically by a Merck RQflex10 reflectometer according to the company protocols (Merck, Darmstadt, Germany)), and the 
total $\mathrm{N}$ uptake during the cultivation cycle was determined. Nitrogen use efficiency (NUE) [35] was calculated as NUE $\left(\mathrm{g} \mathrm{DW} \mathrm{g}^{-1} \mathrm{~N}\right)=$ plant total dry weight $(\mathrm{g}) /$ plant $\mathrm{N}$ uptake $(\mathrm{g})$.

Stomatal conductance was measured (15 days after transplant) with a diffusion porometer (AP4, Delta-T Devices Ltd., Cambridge, England) on two recently expanded unshaded leaves of 20 plants for each replicate.

Leaf lettuce and rocket plants were harvested 22 days after transplant, and the marketable yield was calculated after eliminating decayed or yellowed older leaves. Then, 20 plants were randomly selected for each replicate and destructively sampled. Plant height, plant weight, leaf number, leaf weight, main leaf width (leaf lettuce), petiole length (rocket), and leaf area were determined. Leaf weight was used to calculate the yield of minimally processed product (\%). The leaf area was determined by digital image analysis. Soon after sampling, leaves were weighed and immediately scanned at $350 \mathrm{dpi}$ (Epson Perfection 4180 Photo, Seiko Epson Corp., Suwa, Japan); the image analysis was performed with the ImageJ 1.52a software (National Institutes Health, Bethesda, MD, USA). Scanned leaves were dried at $85{ }^{\circ} \mathrm{C}$ to a constant weight and re-weighed in order to calculate the specific leaf area $\left(\mathrm{SLA} \mathrm{cm} \mathrm{g}^{-1}\right.$ ) as leaf area/leaf dry weight. Afterward, another 20 plants randomly sampled for each replicate were separated into epigeal (stems and leaves) and hypogeal (roots) parts, weighed, and then dried to constant weight at $85^{\circ} \mathrm{C}$ to determine the fresh and dry biomass.

A third sample of 20 plants for each replicate was used for leaf color measure and chemical determinations. Leaf color components $\mathrm{L}^{*}$ (lightness), $\mathrm{a}^{*}$ (positive values for reddish colors and negative values for greenish colors) and $b^{*}$ (positive values for yellowish colors and negative values for bluish colors), were recorded with a colorimeter (CR-400, Minolta corporation, Ltd., Osaka, Japan) at two areas of photosynthetic tissue on the upper part of 20 leaves, randomly selected for each leafy vegetable and each treatment. Hue angle $\left(h^{\circ}\right)$ and Chroma $\left(C^{*}\right)$ were calculated as $h^{\circ}=180^{\circ}$ $+\arctan \left(b^{*} / a^{*}\right)[36]$ and $C^{*}=\left(a^{* 2}+b^{* 2}\right)^{1 / 2}$. Twenty grams of leaves from each sample were then homogenized with $\mathrm{H}_{2} \mathrm{O}(1: 2 \mathrm{w} / \mathrm{v})$ and the homogenates were centrifuged at $3500 \mathrm{rpm}$ for $15 \mathrm{~min}$. The extracts were used to determine soluble solids content (SSC), ascorbic acid and nitrate contents, and titratable acidity (TA). SSC ( ${ }^{\circ}$ Brix) determination was performed on the extracts with a digital refractometer (MTD-045nD, Three-In-One Enterprises Co. Ltd., New Taipei City, Taiwan) [37]. TA (expressed as mg of citric acid per $100 \mathrm{~g}$ of fresh weight) was determined by titrating $10 \mathrm{~mL}$ of the extract with $0.1 \mathrm{M} \mathrm{NaOH}$ up to $\mathrm{pH} 8.1$ [38]. Ascorbic acid and nitrate contents (expressed as $\mathrm{mg}^{100 \mathrm{~g}^{-1}}$ and $\mathrm{mg} \mathrm{kg}^{-1}$ of fresh weight, respectively) were determined reflectometrically by a Merck RQflex10 reflectometer according to the company protocols (Merck, Darmstadt, Germany) [39-41].

\subsection{Statistics and Principal Component Analysis}

The experimental layout consisted of four replicates for each combination of $\mathrm{NaCl}$ and $\mathrm{GA}_{3}$ levels and each leafy vegetable randomly assigned in four blocks. To determine the effect of the $\mathrm{NaCl}$ and $\mathrm{GA}_{3}$ on each leafy vegetable, a two-way ANOVA was carried out. Mean values were compared by the least significant differences (LSD) test at $p \leq 5 \%$ to identify significant differences among treatments and significant interactions between factors.

Principal components analysis (PCA) was performed on morphophysiological and phytochemical parameters to study the main parameters that were most effective in discriminating between salt stress levels and $\mathrm{GA}_{3}$ treatment. The input matrix for the analysis consisted of plant height, whole plant fresh weight (FW), shoot (S) FW, roots (R) FW, S/R FW, whole plant dry weight (DW), shoot DW, roots DW, S/R DW, plant dry matter, yield, minimal processing yield, WUE, NUE, leaf no., plant area, leaf

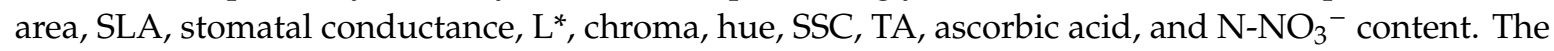
optimum number of principal components (PCs) was assessed by keeping the factors with eigenvalues higher than 1.0. Furthermore, the plot of the PCs allowed investigation of the correlations between the variables of the input data set. With this regard, the initial variables were projected into the subspace defined by the first and second PCs, and correlated variables were determined. The principal component analysis was performed with SPSS version 13.0 (SPSS Inc., Chicago, IL, USA). 


\section{Results}

The average temperature outside the greenhouse, during the experiment, ranged between $21.0 \pm 0.6^{\circ} \mathrm{C}$ (day) and $12.9 \pm 0.4{ }^{\circ} \mathrm{C}$ (night) and the average net solar radiation at noon was $687 \mathrm{~W} \cdot \mathrm{m}^{-2}$. The day length during the cultivation period (from sunrise to sunset) ranged between 12 and $14 \mathrm{~h}$. Inside the greenhouse, the mean air and MNS temperatures were $20.6 \pm 0.5^{\circ} \mathrm{C}$ and $18.8 \pm 0.4{ }^{\circ} \mathrm{C}$, respectively. The air temperature ranged between $36.3 \pm 0.8^{\circ} \mathrm{C}$ (day) and $10.3 \pm 0.4{ }^{\circ} \mathrm{C}$ (night); relative humidity was on average $60.6 \%$ and ranged between $20.2 \%$ and $100 \%$. During the experiment, the highest light intensity inside the greenhouse was 56,020 lux on average, ranging from 72,599 to 10,222 lux as a function of the cloudiness.

The EC and $\mathrm{pH}$ values of the nutrient solutions in the tubes varied during plant growth. The $\mathrm{pH}$ increased up to 6.89 and 6.67 for lettuce and rocket, respectively, regardless of the $\mathrm{GA}_{3}$ or salt content. The EC of MNS had significant differences due to water absorption, as well as to refills of the tubes with MNS with different $\mathrm{NaCl}$ concentrations. The MNS of lettuce plants decreased their EC in control tubes $\left(1.72 \mathrm{mS} \mathrm{cm}^{-1}\right.$ on average for $\left.0 \mathrm{mM} \mathrm{NaCl}\right)$, whereas it increased as increasing salinity of MNS (3.78 and $6.04 \mathrm{~m} \mathrm{mS} \mathrm{cm}^{-1}$ on average for 10 and $20 \mathrm{mM}$, respectively). A similar trend was found for the MNS of rocket plants at harvest, which had an EC of 2.13, 3.84, and 5.53 for 0,10 , and $20 \mathrm{mM}$ $\mathrm{NaCl}$, respectively.

\subsection{Morphophysiological Parameters and Yield of Leaf Lettuce}

The morphological characteristics of lettuce plants were modified by the salinity and $\mathrm{GA}_{3}$ content of the nutrient solution. At harvest, the height of leaf lettuce plants was found to be significantly influenced by the EC of the nutrient solution and by the presence of $\mathrm{GA}_{3}$ in the MNS (Table 1). A reduction of plant height was found, starting with moderate salt stress $(-6 \%$ for plants grown with $10 \mathrm{mM} \mathrm{NaCl}$ in the nutrient solution), whereas plants grown with $10^{-6} \mathrm{M} \mathrm{GA}_{3}$ in the MNS were $2.3 \mathrm{~cm}$ higher than control plants $(24.6 \mathrm{~cm})$. The fresh biomass of lettuce plants was negatively affected by salt stress as it dropped from $13.5 \mathrm{~g} \mathrm{plant}^{-1}$ in control plants to $11.6 \mathrm{~g} \mathrm{plant}^{-1}$ on average for the plants grown in MNS with added $\mathrm{NaCl}$. The fresh weight of the plants grown with $10^{-6} \mathrm{M} \mathrm{GA}_{3}$ in the MNS was $30.3 \%$ higher on average than plants grown without $\mathrm{GA}_{3}$ in the MNS (Table 1). The highest fresh biomass was produced by plants grown with $\mathrm{GA}_{3}$ and $0 \mathrm{mM} \mathrm{NaCl}$ in the MNS; control plants and plants treated with $\mathrm{GA}_{3}$ showed a similar decreasing trend in plant fresh weight $(-16 \%)$, but the plants grown with $\mathrm{GA}_{3}$ at the highest $\mathrm{NaCl}$ concentration had a total fresh weight higher than the control plants (Table 1). The same effect of $\mathrm{GA}_{3}$ and $\mathrm{NaCl}$ was found considering the fresh weight of the shoot and the roots but to a different extent so that the $\mathrm{S} / \mathrm{R}$ ratio significantly increased only as a function of $\mathrm{GA}_{3}$ (Table 1).

Table 1. Morphological parameters of leaf lettuce plants grown in nutrient solutions containing different levels of $\mathrm{NaCl}$ and $\mathrm{GA}_{3}$.

\begin{tabular}{|c|c|c|c|c|c|c|c|c|c|c|c|c|c|c|c|c|c|c|c|c|}
\hline \multirow{2}{*}{\multicolumn{2}{|c|}{$\begin{array}{l}\text { Source of } \\
\text { Variance }\end{array}$}} & \multirow{2}{*}{\multicolumn{2}{|c|}{$\begin{array}{l}\text { Plant Height } \\
\text { (cm) }\end{array}$}} & \multicolumn{8}{|c|}{ Plant Fresh Weight } & \multicolumn{8}{|c|}{ Plant Dry Weight } & \multirow{2}{*}{$\begin{array}{c}\text { Dry } \\
\text { Matter (\%) }\end{array}$} \\
\hline & & & & \multicolumn{2}{|c|}{$\begin{array}{l}\text { Whole } \\
\text { Plant (g) }\end{array}$} & \multicolumn{2}{|c|}{$\begin{array}{l}\text { Shoot } \\
\text { (g) }\end{array}$} & \multicolumn{2}{|c|}{$\begin{array}{l}\text { Roots } \\
\text { (g) }\end{array}$} & \multicolumn{2}{|c|}{$\begin{array}{l}\text { S/R } \\
\text { Ratio }\end{array}$} & \multicolumn{2}{|c|}{$\begin{array}{l}\text { Whole } \\
\text { Plant (g) }\end{array}$} & \multicolumn{2}{|c|}{$\begin{array}{l}\text { Shoot } \\
\text { (g) }\end{array}$} & \multicolumn{2}{|c|}{$\begin{array}{l}\text { Roots } \\
\text { (g) }\end{array}$} & \multicolumn{2}{|c|}{$\begin{array}{c}\text { S/R } \\
\text { Ratio }\end{array}$} & \\
\hline \multicolumn{2}{|c|}{$\mathrm{NaCl}(\mathrm{mM})$} & & & & & & & & & & & & & & & & & & & \\
\hline & & z 26.8 & $\mathrm{a}$ & 13.5 & a & 12.2 & a & 1.3 & a & 9.3 & & 0.51 & & 0.44 & & 0.07 & & 6.1 & & 3.8 \\
\hline & & 25.2 & $\mathrm{~b}$ & 11.9 & $\mathrm{~b}$ & 10.8 & $\mathrm{~b}$ & 1.1 & $\mathrm{~b}$ & 10.0 & & 0.47 & & 0.41 & & 0.06 & & 7.1 & & 4.0 \\
\hline & & 25.4 & $\mathrm{~b}$ & 11.3 & $\mathrm{~b}$ & 10.3 & $\mathrm{~b}$ & 1.0 & $\mathrm{~b}$ & 10.4 & & 0.48 & & 0.41 & & 0.07 & & 6.2 & & 4.2 \\
\hline \multicolumn{21}{|c|}{$\mathrm{GA}_{3}(\mathrm{M})$} \\
\hline & & 24.6 & $\mathrm{~b}$ & 10.6 & $\mathrm{~b}$ & 9.6 & $\mathrm{~b}$ & 1.0 & $\mathrm{~b}$ & 9.2 & $\mathrm{~b}$ & 0.42 & & 0.36 & & 0.06 & & 6.0 & $\mathrm{~b}$ & 4.0 \\
\hline & & 26.9 & a & 13.8 & a & 12.6 & a & 1.2 & a & 10.6 & a & 0.56 & & 0.49 & & 0.07 & & 7.0 & $\mathrm{a}$ & 4.0 \\
\hline \multicolumn{21}{|c|}{$\mathrm{NaCl} \times \mathrm{GA}_{3}$} \\
\hline \multirow[t]{2}{*}{0} & 0 & 26.2 & & 11.7 & & 10.5 & & 1.2 & & 8.9 & & 0.42 & c & 0.35 & c & 0.06 & $\mathrm{~b}$ & 5.8 & & $3.6 \mathrm{~b}$ \\
\hline & $10^{-6}$ & 27.4 & & 15.2 & & 13.8 & & 1.4 & & 9.8 & & 0.60 & a & 0.53 & a & 0.08 & $\mathrm{a}$ & 6.5 & & $4.0 \mathrm{ab}$ \\
\hline \multirow[t]{2}{*}{10} & 0 & 23.6 & & 10.3 & & 9.3 & & 1.0 & & 9.0 & & 0.39 & c & 0.34 & c & 0.05 & $\mathrm{~b}$ & 6.6 & & $3.8 \mathrm{~b}$ \\
\hline & $10^{-6}$ & 26.8 & & 13.4 & & 12.3 & & 1.1 & & 10.9 & & 0.56 & $a b$ & 0.49 & $\mathrm{ab}$ & 0.07 & $\mathrm{ab}$ & 7.6 & & $4.1 \mathrm{ab}$ \\
\hline
\end{tabular}


Table 1. Cont.

\begin{tabular}{|c|c|c|c|c|c|c|c|c|c|c|c|c|c|c|c|}
\hline \multirow{2}{*}{\multicolumn{2}{|c|}{$\begin{array}{l}\text { Source of } \\
\text { Variance }\end{array}$}} & \multirow{3}{*}{$\begin{array}{c}\begin{array}{c}\text { Plant Height } \\
\text { (cm) }\end{array} \\
24.1\end{array}$} & \multicolumn{4}{|c|}{ Plant Fresh Weight } & \multicolumn{7}{|c|}{ Plant Dry Weight } & \multirow{2}{*}{\multicolumn{2}{|c|}{$\begin{array}{c}\text { Dry } \\
\text { Matter (\%) }\end{array}$}} \\
\hline & & & \multirow{2}{*}{$\begin{array}{c}\begin{array}{c}\text { Whole } \\
\text { Plant (g) }\end{array} \\
9.8\end{array}$} & \multirow{2}{*}{$\begin{array}{c}\begin{array}{c}\text { Shoot } \\
\text { (g) }\end{array} \\
8.9\end{array}$} & \multirow{2}{*}{$\begin{array}{c}\begin{array}{c}\text { Roots } \\
\text { (g) }\end{array} \\
0.9\end{array}$} & \multirow{2}{*}{$\begin{array}{c}\begin{array}{c}\text { S/R } \\
\text { Ratio }\end{array} \\
9.8\end{array}$} & \multicolumn{2}{|c|}{$\begin{array}{c}\text { Whole } \\
\text { Plant (g) }\end{array}$} & \multicolumn{2}{|c|}{$\begin{array}{l}\text { Shoot } \\
\text { (g) }\end{array}$} & \multicolumn{2}{|c|}{$\begin{array}{l}\text { Roots } \\
\text { (g) }\end{array}$} & \multirow{2}{*}{$\begin{array}{c}\begin{array}{c}\text { S/R } \\
\text { Ratio }\end{array} \\
5.5\end{array}$} & & \\
\hline 20 & 0 & & & & & & 0.45 & $\mathrm{bc}$ & 0.38 & $\mathrm{bc}$ & 0.07 & $a b$ & & 4.5 & $\mathrm{a}$ \\
\hline & $10^{-6}$ & 26.6 & 12.8 & 11.7 & 1.1 & 11.1 & 0.51 & $\mathrm{~b}$ & 0.44 & $\mathrm{~b}$ & 0.07 & $\mathrm{~b}$ & 6.9 & 4.0 & $a b$ \\
\hline \multicolumn{16}{|c|}{ Significance $^{x}$} \\
\hline & & $* *$ & $* *$ & $* *$ & $* * *$ & ns & $\mathrm{n}$ & & ns & & * & & ns & & $* *$ \\
\hline & & $* * *$ & $* * *$ & $* * * *$ & ** & * & *** & & $* * *$ & & ** & & $* *$ & & ns \\
\hline $\mathrm{NaC}$ & $\mathrm{GA}_{3}$ & ns & ns & ns & ns & ns & * & & * & & * & & ns & & $* *$ \\
\hline
\end{tabular}

${ }^{\mathrm{z}}$ Each value is the mean of 4 replicated samples of 20 plants each. For each factor, values in a column followed by the same letter are not significantly different, according to the LSD test. ${ }^{\times}$Significance: $\mathrm{ns}=$ not significant; * significant at $p<0.05 ;{ }^{* *}$ significant at $p<0.01 ; * * *$ significant at $p<0.001$.

The dry biomass of lettuce plants was positively affected by $\mathrm{GA}_{3}$ treatment that significantly interacted with salt stress (Table 1, Figure 2). Increasing salt stress had no effect on the dry weight of control plants, whereas $\mathrm{GA}_{3}$-treated plants had a significantly higher dry weight than control plants at 0 and $10 \mathrm{mM} \mathrm{NaCl}$ and significantly reduced the dry biomass with the highest $\mathrm{NaCl}$ concentration to values similar to those of the untreated plants. A similar trend was recorded considering the shoot and the roots. An opposite trend was found after analyzing the dry matter percentage of the lettuce plants. In fact, the plants grown on MNS with $\mathrm{GA}_{3}$ had almost a constant dry matter percentage even when increasing the salt stress $(4 \%)$, while control plants significantly increased their dry matter percentage from $3.6 \%$ at $0 \mathrm{mM} \mathrm{NaCl}$ to $4.5 \%$ at $20 \mathrm{Mm} \mathrm{NaCl}$.

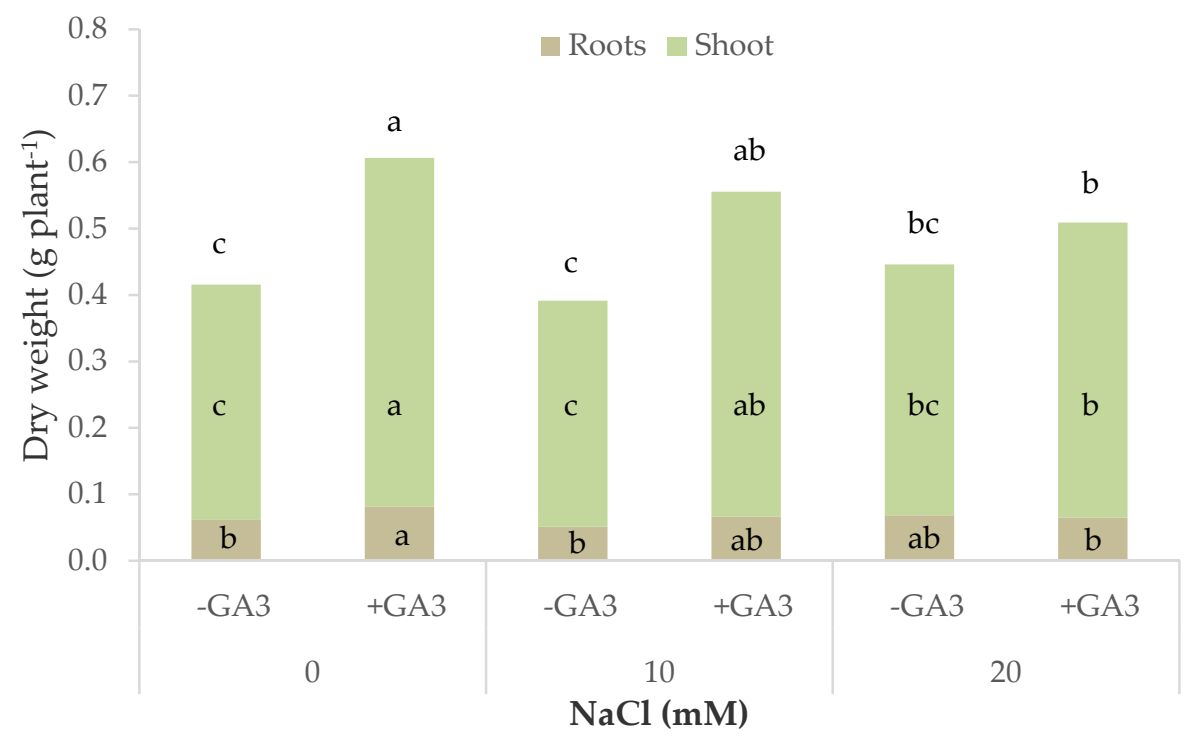

Figure 2. Total, shoot, and root dry biomass of leaf lettuce plants grown in nutrient solutions containing different levels of $\mathrm{NaCl}$ and gibberellic acid $\left(10^{-6} \mathrm{M} \mathrm{GA}_{3}\right)$ (bars of the same color with different letters are significantly different at $p<0.05$ according to the LSD test).

The plants of lettuce not subjected to salt stress yielded $3.6 \mathrm{~kg} \mathrm{~m}^{-2}$ on average; the use of MNS with $\mathrm{NaCl}$ determined a reduction of the crop yield that was similar for the two $\mathrm{NaCl}$ levels tested $(-13.2 \%$ on average for 10 and $20 \mathrm{mM} \mathrm{NaCl}$ ) (Table 2). The plants grown without $\mathrm{GA}_{3}$ yielded $2.9 \mathrm{~kg} \mathrm{~m}^{-2}$ on average, while the addition of $\mathrm{GA}_{3}$ to the MNS allowed a higher yield at each $\mathrm{NaCl}$ level $(+31.7 \%)$ so that the supply of $\mathrm{GA}_{3}$ in brackish MNS allowed the plants to reach a crop yield similar to those grown without $\mathrm{GA}_{3}$ and $0 \mathrm{mM} \mathrm{NaCl}$. The percentage of the yield suitable to become ready to eat produce was significantly affected by salt stress and $\mathrm{GA}_{3}$ supplementation. The minimal processing yield dropped below $90 \%$ on average at the highest salt stress level and was positively influenced by $\mathrm{GA}_{3}(89.2 \%$ and $91.3 \%$ for $0 \mathrm{M}$ and $10^{-6} \mathrm{M} \mathrm{GA}_{3}$, respectively). 
Table 2. Yield parameters of leaf lettuce plants grown in nutrient solutions containing different levels of $\mathrm{NaCl}$ and $\mathrm{GA}_{3}$.

\begin{tabular}{|c|c|c|c|c|c|c|c|c|c|}
\hline \multicolumn{2}{|c|}{ Source of Variance } & \multicolumn{2}{|c|}{ Crop Yield $\left(\mathrm{kg} \mathrm{m}^{2}\right)$} & \multicolumn{2}{|c|}{$\begin{array}{c}\text { Minimal Processing } \\
\text { Yield (\%) }\end{array}$} & \multicolumn{2}{|c|}{ WUE $\left(\mathrm{g} \mathrm{DW} \mathrm{L}^{-1} \mathrm{H}_{2} \mathrm{O}\right.$ ) } & \multicolumn{2}{|c|}{ NUE $\left(g\right.$ DW $\left.g^{-1} \mathrm{~N}\right)$} \\
\hline \multicolumn{10}{|c|}{$\mathrm{NaCl}(\mathrm{mM})$} \\
\hline & & z 3.6 & a & 91.0 & a & 4.5 & & 14.4 & \\
\hline & & 3.2 & $\mathrm{~b}$ & 90.6 & a & 4.6 & & 15.0 & \\
\hline & & 3.1 & $\mathrm{~b}$ & 89.1 & $\mathrm{~b}$ & 4.3 & & 13.7 & \\
\hline \multicolumn{10}{|c|}{$\mathrm{GA}_{3}(\mathrm{M})$} \\
\hline & & 2.9 & $\mathrm{~b}$ & 89.2 & $\mathrm{~b}$ & 3.9 & $\mathrm{~b}$ & 12.3 & b \\
\hline & & 3.8 & a & 91.3 & a & 5.1 & $\mathrm{a}$ & 16.5 & a \\
\hline \multicolumn{10}{|c|}{$\mathrm{NaCl} \times \mathrm{GA}_{3}$} \\
\hline \multirow[t]{2}{*}{0} & 0 & 3.2 & & 90.0 & & 3.9 & & 12.2 & \\
\hline & $10^{-6}$ & 4.1 & & 92.0 & & 5.2 & & 16.7 & \\
\hline \multirow[t]{2}{*}{10} & 0 & 2.8 & & 90.1 & & 4.0 & & 12.7 & \\
\hline & $10^{-6}$ & 3.7 & & 91.1 & & 5.3 & & 17.3 & \\
\hline \multirow[t]{2}{*}{20} & 0 & 2.7 & & 87.6 & & 3.8 & & 11.9 & \\
\hline & $10^{-6}$ & 3.5 & & 90.7 & & 4.8 & & 15.5 & \\
\hline \multicolumn{10}{|c|}{ Significance $^{\mathrm{x}}$} \\
\hline & & \multicolumn{2}{|c|}{ ** } & \multicolumn{2}{|c|}{$* *$} & \multicolumn{2}{|l|}{ ns } & \multicolumn{2}{|c|}{ ns } \\
\hline & & \multicolumn{2}{|c|}{$* * *$} & \multicolumn{2}{|c|}{$* * *$} & \multicolumn{2}{|l|}{$* * *$} & \multicolumn{2}{|c|}{$* * *$} \\
\hline $\mathrm{Na}$ & $\mathrm{GA}_{3}$ & \multicolumn{2}{|c|}{ ns } & \multicolumn{2}{|c|}{ ns } & $\mathrm{ns}$ & & \multicolumn{2}{|c|}{$\mathrm{ns}$} \\
\hline
\end{tabular}

${ }^{\mathrm{z}}$ Each value is the mean of 4 replicated tubs with 150 plants each. For each factor, values in a column followed by the same letter are not significantly different, according to the LSD test. ${ }^{x}$ Significance: $n s=$ not significant; ** significant at $p<0.01 ; * * *$ significant at $p<0.001$.

During plant growth, the MNS taken up by the plants was periodically replenished, and its consumption was recorded for each tube. From these data, we calculated the water use efficiency (WUE) and nitrogen use efficiency (NUE), which were, respectively, $3.9 \mathrm{~g} \mathrm{DW} \mathrm{L}^{-1} \mathrm{H}_{2} \mathrm{O}$ and $12.3 \mathrm{~g} \mathrm{DW} \mathrm{g}^{-1} \mathrm{~N}$ on average in the plants not supplied with $\mathrm{GA}_{3}$. WUE and NUE increased by adding $\mathrm{GA}_{3}$ in the MNS $(+31.5 \%$ and $+34.2 \%$, respectively) but were not influenced by salt stress (Table 2$)$.

Gibberellic acid and salt stress also affected the leaf characteristics of lettuce plants (Table 3). The number of leaves per plant decreased due to increasing salt stress but was positively affected by the $\mathrm{GA}_{3}$ in the MNS. Gibberellic acid also significantly influenced the leaf morphology, enlarging leaf width. This determined an increase of the area of each leaf $\left(+3.6 \mathrm{~cm}^{2}\right.$ leaf $^{-1}$, on average), resulting in a greater total leaf area per plant $\left(+79.4 \mathrm{~cm}^{2}\right.$ plant $^{-1}$, on average). These parameters were higher in the plants grown without $\mathrm{NaCl}$ in the MNS $\left(78.0 \mathrm{~cm}^{2}\right.$ leaf $^{-1}, 721.5 \mathrm{~cm}^{2}$ plant $\left.^{-1}\right)$, and decreased significantly in salt-stressed plants $(-15.9 \%$ and $-22.1 \%$ on average, respectively). The specific leaf area (SLA) was $703.2 \mathrm{~cm}^{2} \mathrm{~g}^{-1} \mathrm{DW}$ on average in the unstressed plants and decreased significantly by adding 10 or $20 \mathrm{mM} \mathrm{NaCl}$ in the MNS. Leaf thickness was also influenced by the presence of $\mathrm{GA}_{3}$ in the MNS that raised SLA by $5.1 \%$ on average (Table 3). 
Table 3. Leaf characteristics of leaf lettuce plants grown in nutrient solutions containing different levels of $\mathrm{NaCl}$ and $\mathrm{GA}_{3}$.

\begin{tabular}{|c|c|c|c|c|c|c|c|c|c|c|c|c|c|}
\hline \multirow{2}{*}{\multicolumn{2}{|c|}{$\begin{array}{l}\begin{array}{l}\text { Source of } \\
\text { Variance }\end{array} \\
\mathrm{NaCl}(\mathrm{mM})\end{array}$}} & \multicolumn{2}{|c|}{$\begin{array}{l}\text { Number of } \\
\text { Leaves }\end{array}$} & \multicolumn{2}{|c|}{$\begin{array}{l}\text { Leaf Width } \\
\text { (cm) }\end{array}$} & \multicolumn{2}{|c|}{$\begin{array}{l}\text { Leaf Area }\left(\mathrm{cm}^{2}\right. \\
\left.\text { Plant }^{-1}\right)\end{array}$} & \multicolumn{2}{|c|}{$\begin{array}{c}\text { Leaf Area } \\
\left(\mathrm{cm}^{2} \text { Leaf }^{-1}\right)\end{array}$} & \multicolumn{2}{|c|}{$\begin{array}{c}\mathrm{SLA}\left(\mathrm{cm}^{2} \mathrm{~g}\right. \\
\left.\mathrm{DW}^{-1}\right)\end{array}$} & \multicolumn{2}{|c|}{$\begin{array}{c}\text { Stomatal } \\
\text { Conductance } \\
\left(\mathrm{mmol} \mathrm{m}^{2} \mathrm{~s}^{-1}\right)\end{array}$} \\
\hline & & & & & & & & & & & & & \\
\hline & & z 9.3 & $\mathrm{a}$ & 11.7 & & 721.5 & $\mathrm{a}$ & 78.0 & a & 703.2 & $\mathrm{a}$ & 567.5 & $\mathrm{a}$ \\
\hline & & 8.7 & $a b$ & 11.1 & & 574.8 & $\mathrm{~b}$ & 66.2 & $\mathrm{~b}$ & 645.5 & $\mathrm{~b}$ & 511.8 & $\mathrm{~b}$ \\
\hline & & 8.4 & $\mathrm{~b}$ & 11.3 & & 548.9 & $\mathrm{~b}$ & 65.1 & $\mathrm{~b}$ & 637.7 & $\mathrm{~b}$ & 485.6 & b \\
\hline \multicolumn{14}{|c|}{$\mathrm{GA}_{3}(\mathrm{M})$} \\
\hline & & 8.5 & $\mathrm{~b}$ & 11.0 & $\mathrm{~b}$ & 575.4 & $\mathrm{~b}$ & 67.9 & $\mathrm{~b}$ & 645.7 & $\mathrm{~b}$ & 483.8 & $\mathrm{~b}$ \\
\hline & & 9.1 & $\mathrm{a}$ & 11.8 & $\mathrm{a}$ & 654.8 & a & 71.6 & a & 678.5 & $\mathrm{a}$ & 559.5 & a \\
\hline \multicolumn{14}{|c|}{$\mathrm{NaCl} \times \mathrm{GA}_{3}$} \\
\hline \multirow[t]{2}{*}{0} & 0 & 8.9 & & 11.4 & & 680.4 & & 76.7 & & 683.7 & & 497.9 & \\
\hline & $10^{-6}$ & 9.6 & & 12.0 & & 762.6 & & 79.3 & & 722.8 & & 637.1 & \\
\hline \multirow[t]{2}{*}{10} & 0 & 8.4 & & 10.7 & & 527.9 & & 63.2 & & 624.6 & & 487.9 & \\
\hline & $10^{-6}$ & 9.0 & & 11.6 & & 621.8 & & 69.1 & & 666.3 & & 535.8 & \\
\hline \multirow[t]{2}{*}{20} & 0 & 8.1 & & 10.9 & & 517.8 & & 63.9 & & 628.9 & & 465.6 & \\
\hline & $10^{-6}$ & 8.8 & & 11.8 & & 579.9 & & 66.3 & & 646.5 & & 505.6 & \\
\hline \multicolumn{14}{|c|}{ Significance $\mathrm{x}$} \\
\hline \multicolumn{2}{|c|}{$\mathrm{NaCl}$} & \multicolumn{2}{|c|}{ * } & \multicolumn{2}{|c|}{ ns } & \multicolumn{2}{|c|}{$* * *$} & \multicolumn{2}{|c|}{$* * *$} & \multicolumn{2}{|c|}{$* * *$} & \multicolumn{2}{|r|}{ ** } \\
\hline \multicolumn{2}{|c|}{$\mathrm{GA}_{3}$} & \multicolumn{2}{|c|}{$*$} & \multicolumn{2}{|c|}{$* *$} & \multicolumn{2}{|c|}{$* * *$} & \multicolumn{2}{|c|}{$* *$} & \multicolumn{2}{|c|}{$*$} & \multicolumn{2}{|r|}{$* * *$} \\
\hline \multicolumn{2}{|c|}{$\mathrm{NaCl} \times \mathrm{GA}_{3}$} & \multicolumn{2}{|c|}{ ns } & \multicolumn{2}{|c|}{ ns } & \multicolumn{2}{|c|}{ ns } & \multicolumn{2}{|c|}{ ns } & \multicolumn{2}{|c|}{ ns } & & ns \\
\hline
\end{tabular}

${ }^{\mathrm{z}}$ Each value is the mean of 4 replicated samples of 20 plants each. For each factor, values in a column followed by the same letter are not significantly different, according to the LSD test. ${ }^{\times}$Significance: $n s=$ not significant; ${ }^{*}$ significant at $p<0.05 ;{ }^{* *}$ significant at $p<0.01$; ** significant at $p<0.001$.

Nutrient solutions added with $\mathrm{NaCl}$ and $\mathrm{GA}_{3}$ affected leaf physiology as well as leaf morphology as shown by the measures of stomatal conductance. This parameter was affected by the salinity of the nutrient solution that determined a reduction of $12.1 \%$ on average for saline MNS, against the value measured in the unstressed plants $\left(567.5 \mathrm{mmol} \mathrm{m}^{-2} \mathrm{~s}^{-1}\right.$ ) (Table 3). The plants supplied with $\mathrm{GA}_{3}$ had a significant increase of stomatal conductance that was on average $559.5 \mathrm{mmol} \mathrm{m}^{-2} \mathrm{~s}^{-1}, 15.7 \%$ higher than those not supplied with $\mathrm{GA}_{3}\left(483.8 \mathrm{mmol} \mathrm{m}^{-2} \mathrm{~s}^{-1}\right)$ (Table 3).

The leaves of lettuce also showed changes as a function of $\mathrm{GA}_{3}$ or salt stress in their color characteristics. The lightness of the leaf color $\left(\mathrm{L}^{*}\right)$ ranged from 54.8 to 51.1 for the plants not subjected $(0 \mathrm{mM} \mathrm{NaCl})$ or subjected to the salt stress $(20 \mathrm{mM} \mathrm{NaCl})$, respectively (Table 4$)$. The leaf color was significantly greener due to increasing salt stress and in the plants supplied with $\mathrm{GA}_{3}$; leaf saturation (Chroma) was lower in the plants not supplied with $\mathrm{GA}_{3}$ irrespective of salt stress, whereas the plants supplied with $\mathrm{GA}_{3}$ had a more vivid color with $0 \mathrm{mM} \mathrm{NaCl}$ and a less vivid color (lower chroma) in increasing salt stress.

The quality of lettuce plants at harvest was assessed by measuring the soluble solid content (SSC), titratable acidity (TA), and nitrate and ascorbic acid content of the leaves, which represent the edible part of this plant (Table 4). SSC was significantly influenced by salt stress only, which determined a significant increase at the highest concentration of $\mathrm{NaCl}$ in the $\mathrm{MNS}\left(3.4^{\circ} \mathrm{Brix},+23.6 \%\right.$ than $0 \mathrm{mM}$ $\mathrm{NaCl}$ ), whereas TA had different trends as a function of both $\mathrm{GA}_{3}$ and salt stress; TA decreased in increasing salt stress in the plants supplied with $\mathrm{GA}_{3}$, while it had an opposite trend in the plants grown without $\mathrm{GA}_{3}$ in the MNS. The ascorbic acid content showed no difference in the leaves of lettuce plants at $0 \mathrm{mM} \mathrm{NaCl}$ (49.3 mg $100 \mathrm{~g}^{-1} \mathrm{FW}$ on average), but it had a decreasing trend by increasing salt stress in the plants supplied with $\mathrm{GA}_{3}\left(30.5 \mathrm{mg} 100 \mathrm{~g}^{-1} \mathrm{FW}\right.$ with $20 \mathrm{mM} \mathrm{NaCl}$ and $\left.10^{-6} \mathrm{M} \mathrm{GA}_{3}\right)$. Lettuce leaves accumulated a higher amount of nitrate when grown with $\mathrm{GA}_{3}$ in the MNS $\left(2248.3 \mathrm{mg} \mathrm{kg}^{-1} \mathrm{FW}\right.$ on average, $+34.0 \%$ than control plants) (Table 4 ). 
Table 4. Leaf color and chemical characteristics of leaf lettuce plants grown in nutrient solutions containing different levels of $\mathrm{NaCl}$ and $\mathrm{GA}_{3}$.

\begin{tabular}{|c|c|c|c|c|c|c|c|c|c|c|c|c|c|c|}
\hline \multirow{2}{*}{\multicolumn{2}{|c|}{$\begin{array}{l}\begin{array}{l}\text { Source of } \\
\text { Variance }\end{array} \\
\mathrm{NaCl}(\mathrm{mM})\end{array}$}} & \multicolumn{2}{|c|}{$\mathbf{L}^{*}$} & \multicolumn{2}{|c|}{ Chroma } & $\mathrm{Hue}^{\circ}$ & \multicolumn{2}{|c|}{$\begin{array}{c}\text { SSC } \\
\left({ }^{\circ} \text { Brix }\right)\end{array}$} & \multicolumn{2}{|c|}{$\begin{array}{l}\text { TA }^{\text {y }}(\mathrm{mg} 100 \\
\left.\mathrm{g}^{-1} \text { FW }\right)\end{array}$} & \multicolumn{2}{|c|}{$\begin{array}{l}\text { Ascorbic Acid } \\
\left(\mathrm{mg} 100 \mathrm{~g}^{-1} \mathrm{FW}\right)\end{array}$} & \multicolumn{2}{|c|}{$\begin{array}{c}\mathrm{N}-\mathrm{NO}_{3}-(\mathrm{mg} \\
\left.\mathrm{kg}^{-1} \mathrm{FW}\right)\end{array}$} \\
\hline & & & & & & & & & & & & & & \\
\hline \multicolumn{2}{|c|}{0} & $\begin{array}{r}\mathrm{Z} \\
54.8\end{array}$ & $\mathrm{a}$ & 44.2 & & $119.2 \mathrm{c}$ & 2.8 & $\mathrm{~b}$ & 23.7 & & 49.3 & $\mathrm{a}$ & 1922.5 & \\
\hline \multicolumn{2}{|c|}{10} & 53.4 & $\mathrm{a}$ & 44.0 & & $119.8 \mathrm{~b}$ & 3.0 & $a b$ & 22.6 & & 47.8 & $\mathrm{~b}$ & 1925.0 & \\
\hline \multirow{2}{*}{\multicolumn{2}{|c|}{$\begin{array}{c}20 \\
\mathrm{GA}_{3}(\mathrm{M})\end{array}$}} & 51.1 & $\mathrm{~b}$ & 43.5 & & 120.6 a & 3.4 & $\mathrm{a}$ & 22.2 & & 36.5 & $\mathrm{~b}$ & 2042.5 & \\
\hline & & & & & & & & & & & & & & \\
\hline \multicolumn{2}{|c|}{0} & 53.5 & & 43.8 & & $119.6 \mathrm{~b}$ & 3.1 & & 22.8 & & 49.7 & $\mathrm{a}$ & 1678.3 & $\mathrm{~b}$ \\
\hline \multicolumn{2}{|c|}{$10^{-6}$} & 52.7 & & 44.0 & & 120.1 a & 2.9 & & 22.9 & & 39.3 & $b$ & 2248.3 & $\mathrm{a}$ \\
\hline \multicolumn{15}{|c|}{$\mathrm{NaCl} \times \mathrm{GA}_{3}$} \\
\hline \multirow[t]{2}{*}{0} & 0 & 55.7 & & 43.4 & $\mathrm{~b}$ & 118.8 & 2.8 & & 22.6 & $\mathrm{ab}$ & 50.5 & $a b$ & 1650.0 & \\
\hline & $10^{-6}$ & 53.8 & & 45.0 & $\mathrm{a}$ & 119.6 & 2.7 & & 24.8 & a & 48.0 & $a b$ & 2195.0 & \\
\hline \multirow[t]{2}{*}{10} & 0 & 53.4 & & 44.1 & $a b$ & 119.7 & 3.1 & & 20.9 & $\mathrm{~b}$ & 56.0 & $\mathrm{a}$ & 1695.0 & \\
\hline & $10^{-6}$ & 53.5 & & 43.9 & $a b$ & 120.0 & 2.8 & & 24.3 & $\mathrm{ab}$ & 39.5 & $\mathrm{bc}$ & 2155.0 & \\
\hline \multirow[t]{2}{*}{20} & 0 & 51.5 & & 43.9 & $a b$ & 120.5 & 3.5 & & 24.8 & $\mathrm{a}$ & 42.5 & $\mathrm{~b}$ & 1690.0 & \\
\hline & $10^{-6}$ & 50.8 & & 43.1 & $\mathrm{~b}$ & 120.7 & 3.3 & & 19.6 & $\mathrm{~b}$ & 30.5 & c & 2395.0 & \\
\hline \multicolumn{15}{|c|}{ Significance $^{\mathrm{x}}$} \\
\hline \multicolumn{2}{|c|}{$\mathrm{NaCl}$} & \multicolumn{2}{|c|}{$* * *$} & \multicolumn{2}{|c|}{ ns } & $* * *$ & \multicolumn{2}{|c|}{ * } & \multicolumn{2}{|l|}{ ns } & \multicolumn{2}{|c|}{$* * *$} & \multicolumn{2}{|c|}{ ns } \\
\hline & & \multicolumn{2}{|c|}{ ns } & \multicolumn{2}{|c|}{ ns } & $*$ & \multicolumn{2}{|c|}{ ns } & \multicolumn{2}{|l|}{ ns } & \multicolumn{2}{|c|}{$* * *$} & $* * *$ & \\
\hline $\mathrm{NaC}$ & $\mathrm{GA}_{3}$ & & & & & ns & & s & $* * *$ & & & & ns & \\
\hline
\end{tabular}

${ }^{\mathrm{z}}$ Each value is the mean of 4 replicated samples of 20 plants each. For each factor, values in a column followed by the same letter are not significantly different, according to the LSD test. ${ }^{x}$ Significance: ns = not significant; * significant at $p<0.05 ;{ }^{* * *}$ significant at $p<0.001 ;$ y Titratable acidity expressed as citric acid.

\subsection{Morphophysiological Parameters and Yield of Rocket}

The morphological characteristics of rocket plants were affected to a different extent by the $\mathrm{NaCl}$ and $\mathrm{GA}_{3}$ content of the nutrient solution. Plant height was slightly affected only by salt stress, whereas fresh and dry biomass accumulation was affected by both salt stress and $\mathrm{GA}_{3}$ (Table 5). Total plant weight increased as a function of $\mathrm{GA}_{3}$ supplementation from 8.1 to $9.6 \mathrm{~g} \mathrm{plant}^{-1}$ on average, whereas it dropped from $10.3 \mathrm{~g}_{\text {plant }}{ }^{-1}$ of the control plants to $7.8 \mathrm{~g} \mathrm{plant}^{-1}$ with the highest salt stress $(20 \mathrm{mM}$ $\mathrm{NaCl}$ ). This reduction was mainly due to the reduction of the shoot of the plant (S) as the root biomass (R) did not change due to increasing salt stress, whereas $\mathrm{GA}_{3}$ exerted its effect in opposite ways on shoot and roots: The first was positively affected by $\mathrm{GA}_{3}$ while the roots decreased their fresh weight in the presence of $\mathrm{GA}_{3}$ in the MNS (Table 5). These variations determined significant changes in the $\mathrm{S} / \mathrm{R}$ ratio that was significantly lower than the control with $20 \mathrm{mM} \mathrm{NaCl}(-29.4 \%)$ but was higher when $\mathrm{GA}_{3}$ was added to the MNS (+52.6\%).

Table 5. Morphological parameters of rocket plants grown in nutrient solutions containing different levels of $\mathrm{NaCl}$ and $\mathrm{GA}_{3}$.

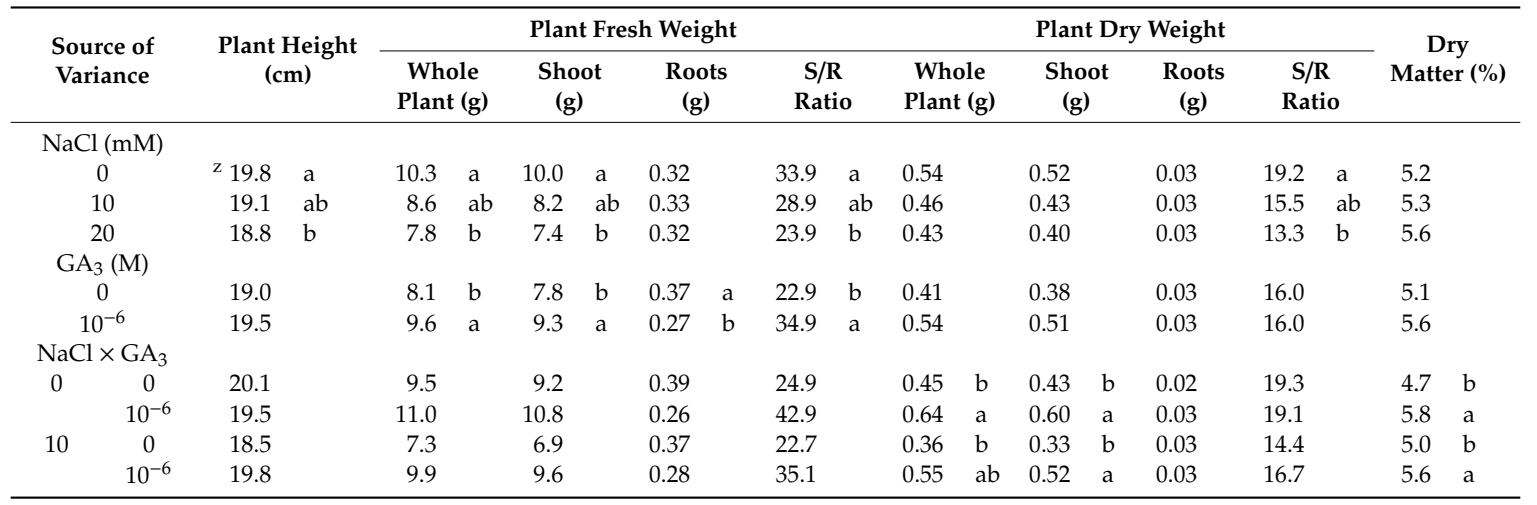


Table 5. Cont.

\begin{tabular}{|c|c|c|c|c|c|c|c|c|c|c|c|c|c|}
\hline \multirow{2}{*}{\multicolumn{2}{|c|}{$\begin{array}{l}\text { Source of } \\
\text { Variance }\end{array}$}} & \multirow{2}{*}{$\begin{array}{c}\begin{array}{c}\text { Plant Height } \\
\text { (cm) }\end{array} \\
18.5\end{array}$} & \multicolumn{4}{|c|}{ Plant Fresh Weight } & \multicolumn{6}{|c|}{ Plant Dry Weight } & \multirow{2}{*}{$\begin{array}{c}\text { Dry } \\
\text { Matter (\%) }\end{array}$} \\
\hline & & & $\begin{array}{c}\begin{array}{c}\text { Whole } \\
\text { Plant (g) }\end{array} \\
7.6\end{array}$ & $\begin{array}{c}\begin{array}{c}\text { Shoot } \\
\text { (g) }\end{array} \\
7.2\end{array}$ & $\begin{array}{c}\begin{array}{c}\text { Roots } \\
\text { (g) }\end{array} \\
0.35\end{array}$ & $\begin{array}{c}\begin{array}{c}\text { S/R } \\
\text { Ratio }\end{array} \\
21.1\end{array}$ & \multicolumn{2}{|c|}{$\begin{array}{l}\text { Whole } \\
\text { Plant (g) }\end{array}$} & \multicolumn{2}{|c|}{$\begin{array}{l}\text { Shoot } \\
\text { (g) }\end{array}$} & $\begin{array}{c}\begin{array}{c}\text { Roots } \\
\text { (g) }\end{array} \\
0.03\end{array}$ & $\begin{array}{r}\begin{array}{c}\text { S/R } \\
\text { Ratio }\end{array} \\
14.2\end{array}$ & \\
\hline & $10^{-6}$ & 19.2 & 7.9 & 7.7 & 0.29 & 26.8 & 0.45 & $\mathrm{~b}$ & 0.41 & $\mathrm{~b}$ & 0.03 & 12.3 & $5.6 \quad \mathrm{a}$ \\
\hline \multicolumn{14}{|c|}{ Significance $^{x}$} \\
\hline \multicolumn{2}{|c|}{$\mathrm{NaCl}$} & * & $* * *$ & $* * *$ & ns & * & \multicolumn{2}{|c|}{$* * *$} & \multicolumn{2}{|c|}{$* * *$} & ns & * & $*$ \\
\hline
\end{tabular}

${ }^{\mathrm{z}}$ Each value is the mean of 4 replicated samples of 20 plants each. For each factor, values in a column followed by the same letter are not significantly different, according to the LSD test. ${ }^{\times}$Significance: $\mathrm{ns}=$ not significant; * significant at $p<0.05 ;{ }^{* *}$ significant at $p<0.01 ; * * *$ significant at $p<0.001$.

The dry biomass of rocket plants was influenced in different ways by salt stress as a function of the $\mathrm{GA}_{3}$ treatments. The plants grown on MNS without $\mathrm{GA}_{3}$ did not significantly change their dry weight due to increasing salt stress, whereas those supplied with $\mathrm{GA}_{3}$ had a significantly higher dry weight with $0 \mathrm{mM} \mathrm{NaCl}$ in the MNS (0.64 $\mathrm{g} \mathrm{DW} \mathrm{plant}^{-1}$ ) and slightly dropped down to $0.45 \mathrm{~g} \mathrm{DW}$ plant $^{-1}$ with $20 \mathrm{mM} \mathrm{NaCl}$, a value that was not significantly different from the plants not treated with $\mathrm{GA}_{3}$ (Table 5, Figure 3). The epigeal part of the plants was similarly affected by the interaction $\mathrm{NaCl} \times$ $\mathrm{GA}_{3}$, but they also accumulated higher dry biomass with $10 \mathrm{mM} \mathrm{NaCl}$ in the MNS while the roots were not affected by salt stress nor by $\mathrm{GA}_{3}$. The distribution of the dry matter between the shoot and roots was significantly affected only by the salt stress as shown by the S/R ratio, which decreased, on average, from 19.2 in the control plants down to 13.3 in the plants grown with $20 \mathrm{mM} \mathrm{NaCl}$ in the MNS (Table 5). The dry matter percentage of the rocket plants showed a significant interaction between salt stress and $\mathrm{GA}_{3}$. The highest salt stress $(20 \mathrm{mM} \mathrm{NaCl})$ determined a significant increase of the dry matter percentage in the plants not treated with $\mathrm{GA}_{3}(5.6 \%,+19.0 \%$ than control), whereas the plants supplied with $\mathrm{GA}_{3}$ had a high dry matter percentage irrespective of the salt stress level ( $5.6 \%$ on average).

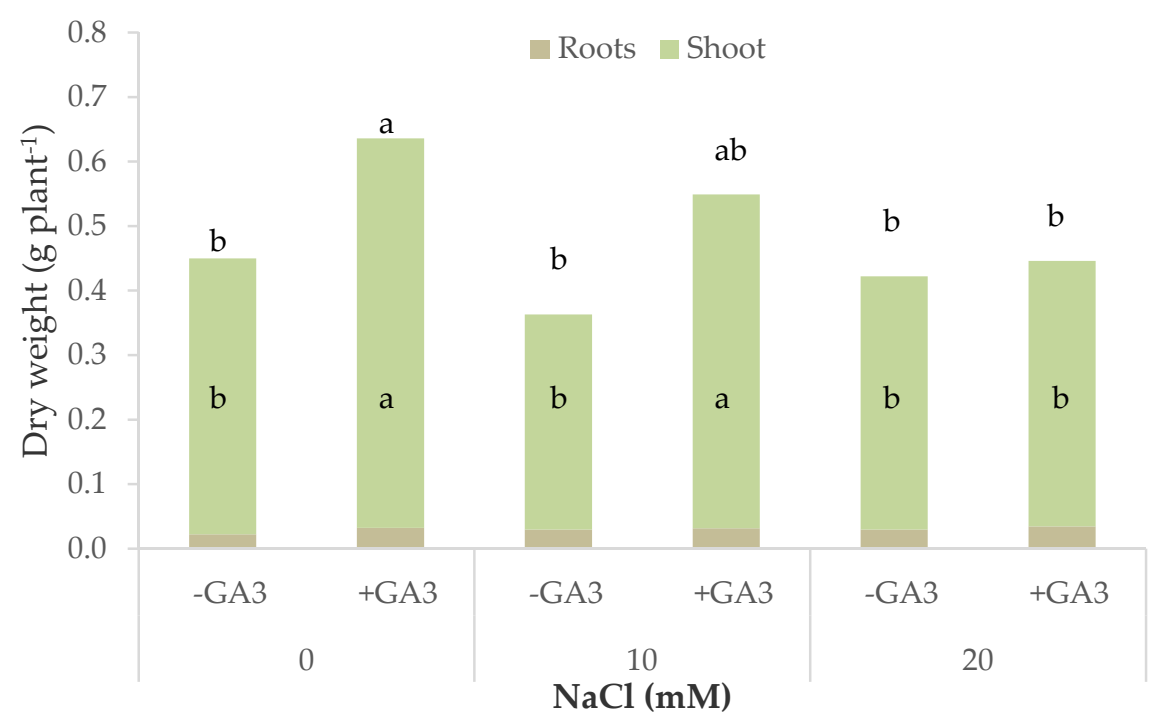

Figure 3. Total, shoot, and root dry biomass of rocket plants grown in nutrient solutions containing different levels of $\mathrm{NaCl}$ and gibberellic acid $\left(10^{-6} \mathrm{M} \mathrm{GA}_{3}\right)$ (bars of the same color with different letters are significantly different at $p<0.05$ according to the LSD test).

As found for lettuce plants, the yield of rocket plants was positively affected by $\mathrm{GA}_{3}$ and negatively by salt stress. The plants of rocket not subjected to salt stress yielded $3.0 \mathrm{~kg} \mathrm{~m}^{-2}$ on average, while yield dropped by $17.4 \%$ and $25.4 \%$ with 10 and $20 \mathrm{mM} \mathrm{NaCl}$, respectively. The plants grown on MNS added with $\mathrm{GA}_{3}$ showed a yield increase of $0.5 \mathrm{~kg} \mathrm{~m}^{-2}$ on average, as compared to controls (Table 6). The part of plants suitable to be minimally processed leaves was $93.7 \%$ on average of the plants grown 
with $\mathrm{GA}_{3}$ irrespective of salt stress. A similar minimal processing yield was calculated for the plants grown without $\mathrm{GA}_{3}$ and with 0 and $10 \mathrm{mM} \mathrm{NaCl}$, while untreated plants grown at the highest salt stress level significantly reduced this parameter (87.4\%) (Table 6).

Table 6. Yield parameters of rocket plants grown in nutrient solutions containing different levels of $\mathrm{NaCl}$ and $\mathrm{GA}_{3}$.

\begin{tabular}{|c|c|c|c|c|c|c|c|c|c|}
\hline \multirow{2}{*}{\multicolumn{2}{|c|}{$\begin{array}{c}\text { Source of Variance } \\
\mathrm{NaCl}(\mathrm{mM})\end{array}$}} & \multicolumn{2}{|c|}{ Crop Yield $\left(\mathrm{kg} \mathrm{m}^{2}\right)$} & \multicolumn{2}{|c|}{$\begin{array}{c}\text { Minimal Processing } \\
\text { Yield (\%) }\end{array}$} & \multicolumn{2}{|c|}{ WUE (g DW L ${ }^{-1} \mathrm{H}_{2} \mathrm{O}$ ) } & \multicolumn{2}{|c|}{ NUE $\left(g^{D W} g^{-1} \mathrm{~N}\right)$} \\
\hline & & & & & & & & & \\
\hline & & z 3.0 & $\mathrm{a}$ & 93.7 & & 2.2 & & 7.6 & \\
\hline & & 2.5 & $\mathrm{~b}$ & 93.4 & & 1.9 & & 6.7 & \\
\hline & & 2.2 & $\mathrm{~b}$ & 90.8 & & 2.2 & & 7.4 & \\
\hline \multicolumn{10}{|c|}{$\mathrm{GA}_{3}(\mathrm{M})$} \\
\hline & & 2.3 & $\mathrm{~b}$ & 91.5 & & 1.9 & & 6.6 & \\
\hline & & 2.8 & $\mathrm{a}$ & 93.7 & & 2.3 & & 8.0 & \\
\hline \multicolumn{10}{|c|}{$\mathrm{NaCl} \times \mathrm{GA}_{3}$} \\
\hline \multirow{2}{*}{0} & 0 & 2.7 & & 93.5 & $\mathrm{a}$ & 1.7 & $\mathrm{~b}$ & 5.9 & c \\
\hline & $10^{-6}$ & 3.2 & & 93.8 & a & 2.6 & $\mathrm{a}$ & 9.3 & $\mathrm{a}$ \\
\hline \multirow[t]{2}{*}{10} & 0 & 2.1 & & 93.6 & a & 1.9 & $\mathrm{~b}$ & 6.4 & c \\
\hline & $10^{-6}$ & 2.9 & & 93.2 & a & 2.0 & $\mathrm{~b}$ & 7.1 & $\mathrm{~b}$ \\
\hline \multirow[t]{2}{*}{20} & 0 & 2.2 & & 87.4 & $\mathrm{~b}$ & 2.1 & $\mathrm{~b}$ & 7.4 & $\mathrm{~b}$ \\
\hline & $10^{-6}$ & 2.3 & & 94.1 & a & 2.2 & $\mathrm{~b}$ & 7.5 & $\mathrm{~b}$ \\
\hline \multicolumn{10}{|c|}{ Significance $\mathrm{x}$} \\
\hline & & \multicolumn{2}{|c|}{$* * *$} & \multicolumn{2}{|c|}{ * } & \multicolumn{2}{|c|}{ ns } & \multicolumn{2}{|c|}{ ns } \\
\hline & & \multicolumn{2}{|c|}{$* * *$} & \multicolumn{2}{|c|}{$*$} & \multicolumn{2}{|c|}{$* * *$} & \multicolumn{2}{|c|}{$* * *$} \\
\hline $\mathrm{Na}$ & $\mathrm{GA}_{3}$ & \multicolumn{2}{|c|}{ ns } & \multicolumn{2}{|c|}{$* *$} & \multicolumn{2}{|c|}{$* *$} & \multicolumn{2}{|c|}{$* *$} \\
\hline
\end{tabular}

${ }^{\mathrm{z}}$ Each value is the mean of 4 replicated tubs with 150 plants each. For each factor, values in a column followed by the same letter are not significantly different, according to the LSD test. ${ }^{\times}$Significance: $n s=$ not significant; * significant at $p<0.05 ;{ }^{* *}$ significant at $p<0.01 ;{ }^{* * *}$ significant at $p<0.001$.

A WUE of $1.7 \mathrm{~g}$ DW L L $\mathrm{H}_{2} \mathrm{O}$ was calculated for rocket plants grown in MNS with the lowest EC $(0 \mathrm{mM} \mathrm{NaCl})$ and without $\mathrm{GA}_{3}$. This parameter increased significantly up to $2.6 \mathrm{~g} \mathrm{DW} \mathrm{L}{ }^{-1} \mathrm{H}_{2} \mathrm{O}$ with only $\mathrm{GA}_{3}$ added to the MNS with $0 \mathrm{mM} \mathrm{NaCl}$ whereas it remained lower in all the other $\mathrm{NaCl} \times \mathrm{GA}_{3}$ combinations (2.1 g DW L ${ }^{-1} \mathrm{H}_{2} \mathrm{O}$ on average) (Table 6). $\mathrm{GA}_{3}$ also exerted its positive effect on NUE of the unstressed rocket plants $(0 \mathrm{mM} \mathrm{NaCl})$, which increased from $5.9 \mathrm{~g} \mathrm{DW} \mathrm{g}^{-1} \mathrm{~N}$ in non-treated plants to $9.3 \mathrm{~g} \mathrm{DW} \mathrm{g}^{-1} \mathrm{~N}_{\text {in }} \mathrm{GA}_{3}$-treated plants (Table 6). The highest salt stress $(20 \mathrm{mM} \mathrm{NaCl})$ determined a significant increase of NUE in untreated plants $\left(7.4 \mathrm{~g} \mathrm{DW} \mathrm{g}^{-1} \mathrm{~N}\right)$ whereas the NUE of the plants supplied with $\mathrm{GA}_{3}$ dropped from 9.3 down to $7.3 \mathrm{~g} \mathrm{DW} \mathrm{g}^{-1} \mathrm{~N}$, on average, when grown in salt stress conditions (Table 6).

The morphological traits of rocket leaves were variously affected by the presence of gibberellic acid in the nutrient solution or by the salt stress (Table 7). The plants supplied with $\mathrm{GA}_{3}$ were leafier than the control plant and both treated and untreated plants slightly but significantly reduced the number of leaves in increasing salt stress (Table 7). The leaves showed modification in their morphology due to salt stress as regards the petiole length and leaf area, which were $8.7 \%$ and $16.9 \%$ smaller than the control, respectively. A similar negative effect of salt stress was also recorded on the total leaf area per plant that dropped from 206.8 to $161.1 \mathrm{~cm}^{2}$ plant $^{-1}$ on average for 10 and $20 \mathrm{mM} \mathrm{NaCl}$. Even if the average leaf area was not affected by $\mathrm{GA}_{3}$, the total leaf area per plant was significantly higher $\left(195.5 \mathrm{~cm}^{2}\right.$ plant $^{-1}$ on average) in the $\mathrm{GA}_{3}$-treated plants than in the untreated plants $\left(157.2 \mathrm{~cm}^{2}\right.$ plant $^{-1}$ on average) (Table 7$)$. 
Table 7. Leaf characteristics of rocket plants grown in nutrient solutions containing different levels of $\mathrm{NaCl}$ and $\mathrm{GA}_{3}$.

\begin{tabular}{|c|c|c|c|c|c|c|c|c|c|c|c|c|}
\hline \multirow{2}{*}{\multicolumn{2}{|c|}{$\begin{array}{l}\begin{array}{l}\text { Source of } \\
\text { Variance }\end{array} \\
\mathrm{NaCl}(\mathrm{mM})\end{array}$}} & \multicolumn{2}{|c|}{$\begin{array}{c}\text { Number of } \\
\text { Leaves }\end{array}$} & \multicolumn{2}{|c|}{$\begin{array}{l}\text { Leaf Width } \\
\quad(\mathrm{cm})\end{array}$} & \multicolumn{2}{|c|}{$\begin{array}{c}\text { Leaf Area } \\
\left(\mathrm{cm}^{2} \text { Plant }^{-1}\right)\end{array}$} & \multicolumn{2}{|c|}{$\begin{array}{c}\text { Leaf Area } \\
\left(\mathrm{cm}^{2} \text { Leaf }^{-1}\right)\end{array}$} & $\begin{array}{c}\text { SLA } \\
\left(\mathrm{cm}^{2} \mathrm{~g} \mathrm{DW}^{-1}\right)\end{array}$ & \multicolumn{2}{|c|}{$\begin{array}{c}\text { Stomatal } \\
\text { Conductance } \\
\left(\mathrm{mmol} \mathrm{m}^{2} \mathrm{~s}^{-1}\right)\end{array}$} \\
\hline & & & & & & & & & & & & \\
\hline & & $\mathrm{z} 10.8$ & a & 9.1 & a & 206.8 & $\mathrm{a}$ & 19.4 & a & 408.1 & 262.9 & \\
\hline & & 10.4 & $\mathrm{ab}$ & 8.3 & $\mathrm{~b}$ & 166.4 & $\mathrm{~b}$ & 15.9 & b & 395.0 & 233.4 & \\
\hline & & 9.6 & b & 8.3 & b & 155.9 & $\mathrm{~b}$ & 16.3 & b & 390.7 & 238.2 & \\
\hline \multicolumn{13}{|c|}{$\mathrm{GA}_{3}(\mathrm{M})$} \\
\hline & & 9.3 & $\mathrm{~b}$ & 8.6 & & 157.2 & $\mathrm{~b}$ & 16.9 & & 411.3 & 234.7 & \\
\hline & & 11.2 & a & 8.6 & & 195.5 & $\mathrm{a}$ & 17.5 & & 384.5 & 254.9 & \\
\hline \multicolumn{13}{|c|}{$\mathrm{NaCl} \times \mathrm{GA}_{3}$} \\
\hline \multirow[t]{2}{*}{0} & 0 & 9.6 & & 9.3 & & 190.2 & & 19.8 & & 446.3 & 227.3 & $\mathrm{~b}$ \\
\hline & $10^{-6}$ & 12.0 & & 9.0 & & 223.3 & & 19.0 & & 369.9 & 298.5 & a \\
\hline \multirow[t]{2}{*}{10} & 0 & 9.1 & & 8.1 & & 131.6 & & 14.5 & & 402.0 & 233.1 & $\mathrm{~b}$ \\
\hline & $10^{-6}$ & 11.7 & & 8.6 & & 201.2 & & 17.4 & & 388.1 & 233.6 & $\mathrm{~b}$ \\
\hline \multirow[t]{2}{*}{20} & 0 & 9.2 & & 8.4 & & 149.8 & & 16.4 & & 385.7 & 243.8 & \\
\hline & $10^{-6}$ & 10.0 & & 8.3 & & 162.0 & & 16.2 & & 395.7 & 232.7 & $\mathrm{~b}$ \\
\hline \multicolumn{13}{|c|}{ Significance $^{\mathrm{x}}$} \\
\hline \multicolumn{2}{|c|}{$\mathrm{NaCl}$} & \multicolumn{2}{|c|}{ * } & \multicolumn{2}{|c|}{ * } & \multicolumn{2}{|c|}{$* * *$} & \multicolumn{2}{|c|}{ * } & ns & \multicolumn{2}{|c|}{ * } \\
\hline \multicolumn{2}{|c|}{$\mathrm{GA}_{3}$} & \multicolumn{2}{|c|}{$* * *$} & \multicolumn{2}{|c|}{ ns } & \multicolumn{2}{|c|}{$* * *$} & \multicolumn{2}{|c|}{ ns } & ns & \multicolumn{2}{|c|}{ ns } \\
\hline \multicolumn{2}{|c|}{$\mathrm{NaCl} \times \mathrm{GA}_{3}$} & \multicolumn{2}{|c|}{ ns } & \multicolumn{2}{|c|}{ ns } & \multicolumn{2}{|c|}{ ns } & \multicolumn{2}{|c|}{ ns } & $\mathrm{ns}$ & \multicolumn{2}{|c|}{ * } \\
\hline
\end{tabular}

${ }^{\mathrm{z}}$ Each value is the mean of 4 replicated samples of 20 plants each. For each factor, values in a column followed by the same letter are not significantly different, according to the LSD test. ${ }^{\times}$Significance: $n s=$ not significant; ${ }^{*}$ significant at $p<0.05 ;{ }^{* * *}$ significant at $p<0.001$.

Unstressed plants beneficiated from $\mathrm{GA}_{3}$ supplementation, which determined a significant increase of stomatal conductance from 227.3 to $298.5 \mathrm{mmol} \mathrm{m}^{2} \mathrm{~s}^{-1}$, but this positive effect was not maintained in salt-stressed plants $\left(235.8 \mathrm{mmol} \mathrm{m}^{2} \mathrm{~s}^{-1}\right.$ on average) (Table 7).

The color of rocket leaves at harvest was significantly affected by salt stress and $\mathrm{GA}_{3}$ supplementation. $\mathrm{L}^{*}$ and Chroma both decreased under salt stress conditions and with $\mathrm{GA}_{3}$ supplementation, whereas the hue angle slightly increased in the stressed plant supplied with $\mathrm{GA}_{3}$. Thus, the leaf color tended to get darker and less vivid due to both salt stress and $\mathrm{GA}_{3}$ and tended to get greener in salt-stressed plants supplied with $\mathrm{GA}_{3}$ (Table 8).

Table 8. Leaf color and chemical characteristics of rocket plants grown in nutrient solutions containing different levels of $\mathrm{NaCl}$ and $\mathrm{GA}_{3}$.

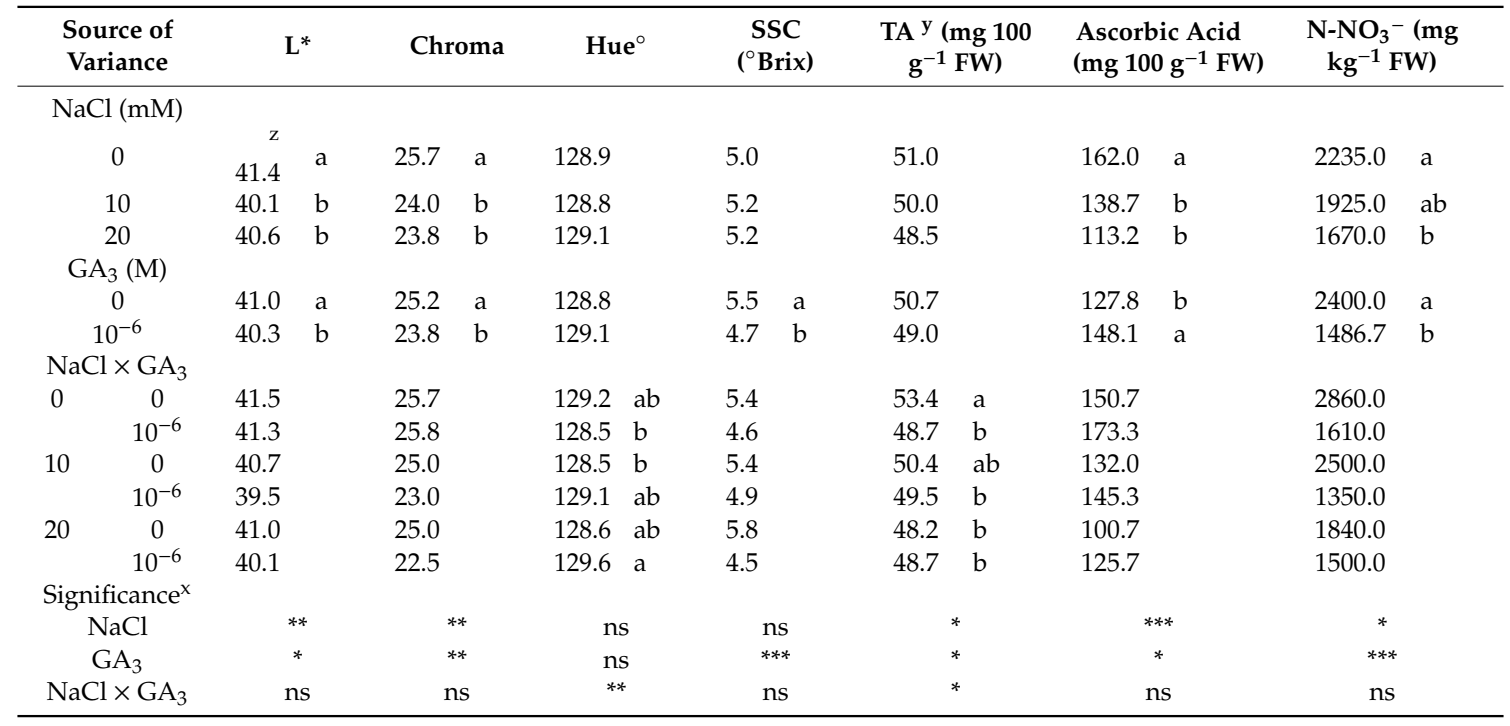

${ }^{\mathrm{z}}$ Each value is the mean of 4 replicated samples of 20 plants each. For each factor, values in a column followed by the same letter are not significantly different, according to the LSD test. ${ }^{x}$ Significance: $\mathrm{ns}=$ not significant; ${ }^{*}$ significant at $p<0.05 ;{ }^{* *}$ significant at $p<0.01 ;{ }^{* * *}$ significant at $p<0.001 ;$ y Titratable acidity expressed as citric acid. 
The chemical characteristics of rocket leaves showed some modifications due to salt stress and/or $\mathrm{GA}_{3}$. The soluble solids content (SSC) was mainly affected by $\mathrm{GA}_{3}$ as this parameter dropped from 5.5 to $4.7^{\circ}$ Brix by adding $\mathrm{GA}_{3}$ in the MNS. Titratable acidity (TA) decreased in increasing salt stress in the plants not supplied with $\mathrm{GA}_{3}$, while the treated plants had an almost constant TA (Table 8). The ascorbic acid content of the unstressed plants was $162.0 \mathrm{mg} 100 \mathrm{~g}^{-1} \mathrm{FW}$ on average and was significantly lower in the stressed plants (138.7 and $113.2100 \mathrm{~g}^{-1} \mathrm{FW}$ on average for 10 and $20 \mathrm{mM} \mathrm{NaCl}$, respectively). The plants supplied with $\mathrm{GA}_{3}$ had a higher ascorbic acid content than the untreated plants at each salinity level ( $+15.9 \%$ on average) (Table 8$)$. A similar effect of salt stress was found for the nitrate content of rocket leaves, which decreased from 2235.0 to $1670.0 \mathrm{mg} \mathrm{kg}^{-1} \mathrm{FW}$ on average, as increasing $\mathrm{NaCl}$ in the MNS from 0 to $20 \mathrm{mM}$, whereas $\mathrm{GA}_{3}$-treated plants had a significantly lower nitrate content (1486.7 $\mathrm{mg} \mathrm{kg}^{-1} \mathrm{FW}$ on average) than control plants (2400.0 $\mathrm{mg} \mathrm{kg}^{-1} \mathrm{FW}$ on average) (Table 8).

\subsection{Principal Components Analysis}

The principal component analysis (PCA) disclosed three principal components (PCs) with eigenvalues higher than 1 (Table 9 ), accounting for $80.61 \%, 10.11 \%$, and $5.18 \%$ of the total variance, respectively. This indicated that the initial 26 variables could be expressed as a linear combination of three PCs, which explain $95.89 \%$ of the total variance. PC1 was mainly related to plant height, whole plant FW, shoot FW, root FW, S/R FW, whole plant DW, shoot DW, root DW, S/R DW, plant dry matter percentage, yield, WUE, NUE, plant and leaf area, SLA, stomatal conductance, leaf color components, SSC, TA, and ascorbic acid content; PC2 was related to minimal processing yield and leaf number; and PC3 was related to nitrate content (Table 9). The projection of the original variables on the plane of the two main PCs could demonstrate such a relationship, as reported in the plot of loadings (Figure 4a). The discrimination of the various $\mathrm{NaCl}$ concentrations $\times \mathrm{GA} 3$ treatments applied to leaf lettuce and rocket plants can be seen in the plot of scores (Figure $4 \mathrm{~b}$ ), where two main clusters could be visibly distinguished. Rocket scores were located in the negative part of the PC1 axis and clearly separated from those of lettuce, located in the positive part of the PC1 axis. The scores of lettuce and rocket plants grown in MNS with added $\mathrm{GA}_{3}$ were in the positive part of the PC2 axis whereas untreated plants were in the negative part of the PC2 axis. The response of lettuce and rocket to salt stress was similar as it determined a decrease of the PC2 values of both vegetables. Lettuce plants showed smaller variations of $\mathrm{PC} 2$ values than rocket plants, which in turn were more responsive to the $\mathrm{GA}_{3}$ treatment.

Table 9. Correlation of variables to the factors of the principal components analysis (PCA) based on factor loadings.

\begin{tabular}{cccc}
\hline Variables & PC1 & PC2 & PC3 \\
\hline Plant height & $\mathbf{0 . 9 8 2}$ & 0.117 & 0.057 \\
Whole plant FW & $\mathbf{0 . 8 1 4}$ & 0.557 & 0.089 \\
Shoot FW & $\mathbf{0 . 7 3 2}$ & 0.658 & 0.092 \\
Root FW & $\mathbf{0 . 9 8 9}$ & -0.021 & 0.076 \\
S/R FW & $\mathbf{- 0 . 8 4 6}$ & 0.486 & -0.158 \\
Whole plant DW & $\mathbf{0 . 9 4 4}$ & 0.283 & -0.034 \\
Shoot DW & $\mathbf{0 . 9 2 2}$ & 0.338 & -0.025 \\
Roots DW & $\mathbf{0 . 9 8 1}$ & -0.022 & -0.052 \\
S/R DW & $\mathbf{- 0 . 8 9 9}$ & 0.323 & 0.181 \\
Plant DM & $\mathbf{- 0 . 8 8 7}$ & 0.192 & -0.272 \\
Yield & $\mathbf{0 . 9 7 9}$ & 0.192 & 0.039 \\
Minimal processing Yield & -0.456 & $\mathbf{0 . 6 3 9}$ & 0.320 \\
\hline
\end{tabular}


Table 9. Cont.

\begin{tabular}{cccc}
\hline Variables & PC1 & PC2 & PC3 \\
\hline WUE & $\mathbf{0 . 9 6 8}$ & 0.149 & -0.020 \\
NUE & $\mathbf{0 . 9 4 7}$ & 0.204 & -0.024 \\
Leaf No. & -0.571 & $\mathbf{0 . 7 6 9}$ & -0.253 \\
Plant area & $\mathbf{0 . 9 8 7}$ & 0.086 & -0.030 \\
Leaf area & $\mathbf{0 . 9 9 3}$ & -0.028 & -0.033 \\
SLA & $\mathbf{0 . 9 8 8}$ & -0.056 & 0.073 \\
Stomatal conductance & $\mathbf{0 . 9 8 7}$ & 0.099 & -0.025 \\
L $^{*}$ & $\mathbf{0 . 9 7 4}$ & -0.106 & -0.038 \\
Chroma & $\mathbf{0 . 9 8 3}$ & -0.107 & -0.015 \\
Hue & $\mathbf{- 0 . 9 8 0}$ & 0.116 & 0.070 \\
SSC & $\mathbf{- 0 . 9 4 4}$ & -0.142 & 0.159 \\
TA & $\mathbf{- 0 . 9 6 8}$ & 0.130 & 0.122 \\
Ascorbic acid & $\mathbf{- 0 . 9 2 6}$ & 0.314 & 0.051 \\
N-NO $^{-}$ & 0.082 & -0.054 & $\mathbf{0 . 9 7 9}$ \\
\hline
\end{tabular}

Values in bold within the same factor indicate the variable with the largest correlation.

Combining the data from the plot of loadings and scores, it can be concluded that $\mathrm{NaCl}$ levels and $\mathrm{GA}_{3}$ treatment influenced the tested species in different ways (Figure $4 \mathrm{a}, \mathrm{b}$ ). Lettuce was related to all parameters positively related to PC1, whereas rocket plants were related to all parameters negatively related to $\mathrm{PC} 1$. The presence of $\mathrm{GA}_{3}$ in the nutrient solution was positively related to $\mathrm{PC} 2$ and partially to PC1 in lettuce plants and only to PC2 in rocket plants. The increase of the $\mathrm{NaCl}$ concentration in the MNS was negatively related to PC2 in rocket and lettuce plants; the latter was also negatively related to $\mathrm{PC} 1$ as regards salt stress. 

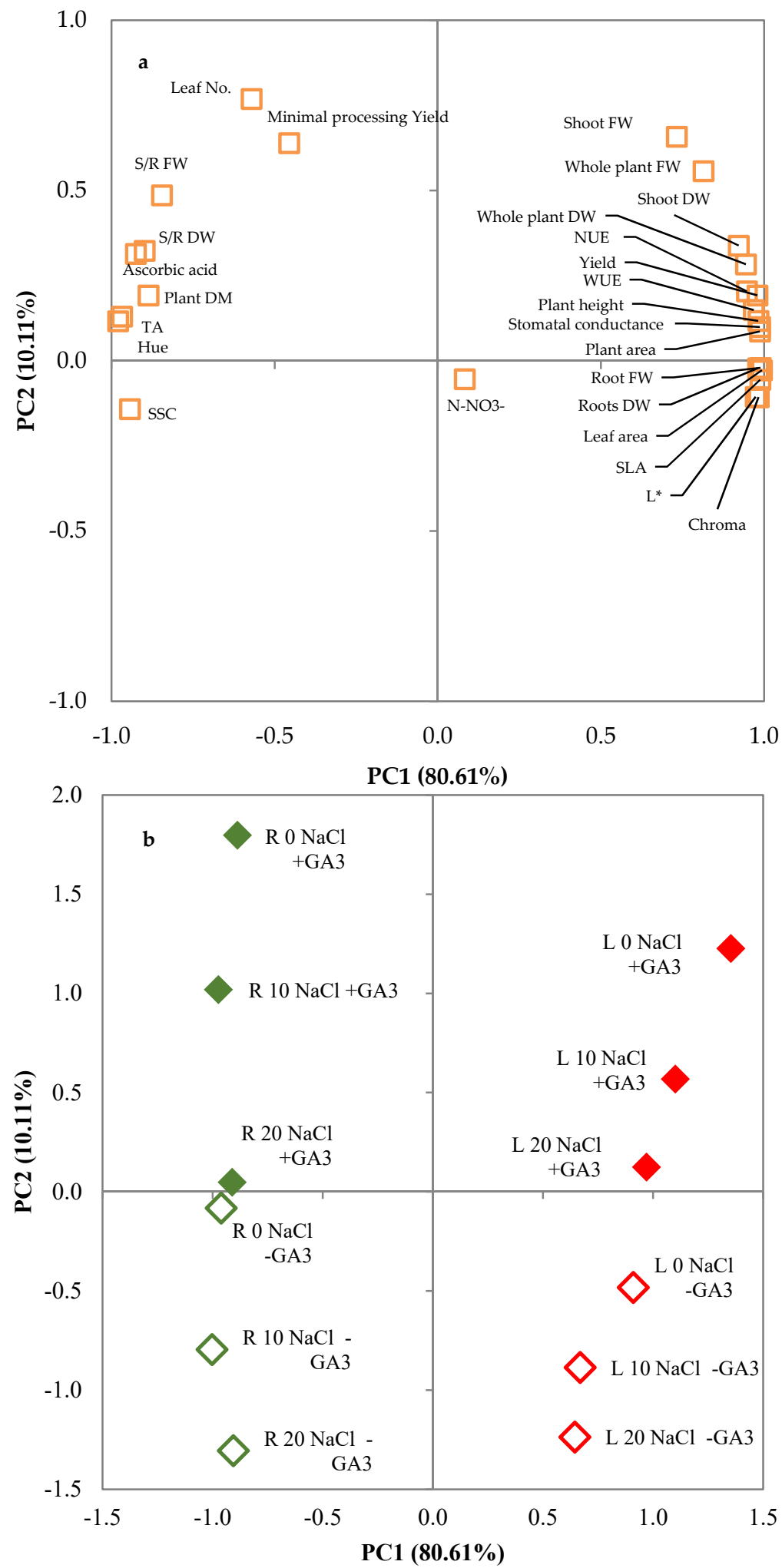

Figure 4. Plot of (a) loadings (morphophysiological and quality characteristics of lettuce and rocket plants) and (b) scores (trials) formed by the two principal components from the Principal Component Analysis (PCA). L: leaf lettuce plants; R: rocket plants; $0 \mathrm{NaCl}, 10 \mathrm{NaCl}, 20 \mathrm{NaCl}: \mathrm{mM}$ of $\mathrm{NaCl}$ in the nutrient solution;-GA3: nutrient solutions not supplemented with gibberellic acid; +GA3: nutrient solutions not supplemented with $10^{-6} \mathrm{M}$ gibberellic acid. 


\section{Discussion}

The evidence that the salt tolerance mechanism in plants is primarily under hormonal control and that plants' response to increased salinity is related to changes in endogenous phytohormone levels has led to studies that aimed to re-equilibrate the phytohormone levels of salt-stressed plants through the exogenous supplementation of plant growth regulators $[18,20,29,42]$. Considering the plants under field conditions, it has been shown that vigorous plants can better cope with salt stress, possibly by increasing the salinity tolerance threshold or delaying its onset [43]. The exogenous supplementation of plant growth regulators, such as gibberellic acid $\left(\mathrm{GA}_{3}\right)$, can be effective in increasing plant growth and vigor and can affect plant metabolism by enhancing $\mathrm{N}$ uptake and assimilation and improving photosynthetic $\mathrm{CO}_{2}$ fixation [31,44,45], thus helping plants to better cope with salt stress. In a previous work [24], we found that leaf lettuce and rocket grown in a floating system showed enhanced growth and quality when $10^{-6} \mathrm{M} \mathrm{GA}_{3}$ was added to the MNS. In this experiment, we tested the possibility of increasing the salinity tolerance threshold of these species by supplying $10^{-6} \mathrm{M} \mathrm{GA}_{3}$ through the mineral nutrient solution of a floating system and evaluated the combined effects of salt stress and $\mathrm{GA}_{3}$ on growth and quality.

Leaf lettuce and rocket were shown to be affected by the salt stress applied to the plants even with a different salinity tolerance threshold. The main visible effect of salinity on vegetables is a reduction of the growth rate, which determines smaller leaves and fruits, shorter plants, and the alteration of other morphological attributes, and ending in a reduction of the plant biomass $[46,47]$. These effects were also found in the tested species. Plant height showed a significant reduction of about $5 \%$ in both lettuce and rocket, but the latter recorded this reduction only at the highest salt stress. The salinity of the MNS also affected the fresh biomass of the plants of both species, but even for this parameter, the reduction was slight and related to the salt stress level in rocket plants whereas it reached a significantly lower value at an intermediate salt stress level in lettuce, confirming that the effects of salinity on vegetables depend on its level [48]. The reduction of fresh biomass could be ascribed to the increased osmotic stress determined by the high EC of the MNS that reduced water uptake and to a modification of plant metabolism and nutrient uptake. Salinity negatively influences the availability of the nutrient elements in the nutrient solution, thus possibly leading to a severe reduction of root growth $[47,48]$. This reduction was more evident for the root fresh weight of lettuce plants and could thus depend on crops and salinity levels. Salt stress can also affect water and nutrient uptake and translocation from the roots to the shoot, determining changes in biomass fractions as shown by the S/R FW ratio of rocket plants. The reduction of the lettuce and rocket fresh biomass induced by the exposure to salinity was mainly due to osmotic effects and changes in the water status of the plants because salt stress did not significantly affect the dry biomass accumulated in the plants of both species. The relative water content of leaves generally decreases in increasing salt stress and this could be due to lower water availability under stress conditions or to disorders of the roots that are not able to sufficiently compensate for the water lost by transpiration $[49,50]$.

Inhibition in plant growth was significantly mitigated by the addition of $\mathrm{GA}_{3}$ to the MNS; the supplementation of gibberellic acid through the nutrient solution was confirmed to have a positive effect on fresh and dry biomass accumulation of the unstressed lettuce and rocket plants [24] and maintained this positive effect in the 10 and $20 \mathrm{mM}$ salt treatments, with the biomass close to the control plants (fresh weight) or even significantly higher as regards the dry biomass. Plant hormones play an important role in plant growth and development and can alleviate the negative effects of salt stress [51]; gibberellic acid was found to be helpful in improving the growth of various crops under saline conditions $[18,31,51,52]$. The exogenous supply of hormones during salt stress may reduce water loss rates and also determine the increase in the leaf water potential and carbon gain rates [53]. The exogenous supplementation of $\mathrm{GA}_{3}$ may exert a positive effect on the growth of the aerial part of the plants by influencing internal resource repartition. The increase of the biomass of aboveground parts may be determined by the rise of many important catabolic pathways (ribose and polyribosome multiplication; DNA, RNA, and protein synthesis) [54-57]. The biomass increase in 
salt-stressed plants treated with $\mathrm{GA}_{3}$ could also be due to enhanced uptake and use of water and mineral nutrients $[27,58,59]$ and transport of photosynthates [60-62], which follow from increased membrane permeability $[63,64]$.

The yield and quality of leafy vegetables are strictly related to the characteristics of the aboveground biomass accumulated by the plants, thus the negative effects of salt stress on plant morphology and development severely impact yield and its economic value. Leaf lettuce and rocket cultivated in soilless systems were shown to be sensitive to salinity $[10,14,65-68]$, and this sensitivity was confirmed in this experiment as they overcame the tolerance threshold starting with the lower $\mathrm{NaCl}$ concentration (10 $\mathrm{mM} ; 3.4 \mathrm{mS} \mathrm{cm}^{-1} \mathrm{EC}$ ), which determined a yield drop by $11.6 \%$ and $24.6 \%$ on average for lettuce and rocket, respectively. Moreover, lettuce and rocket plants recorded a significant drop in the minimal processing yield at $20 \mathrm{mM} \mathrm{NaCl}$ that further increased the reduction in yielded plants and consequently the marketable portion obtainable from salt-stressed plants.

Even for these parameters, $\mathrm{GA}_{3}$ treatment successfully mitigated salt stress and enhanced the salt tolerance of the tested crops. The supply of $10^{-6} \mathrm{M} \mathrm{GA}_{3}$ through the nutrient solution increased the yield parameters in salt-stressed plants to similar or even higher levels than control plants $(0 \mathrm{mM} \mathrm{NaCl}$; $0 \mathrm{M} \mathrm{GA}_{3}$ ). It is well known that the exposure of plants to salinity induces a proportional increase in abscisic acid (ABA) synthesis, which is often related to the leaf water potential [51]. Thus, the increase of the endogenous ABA may be due to a water deficit rather than specific salt effects [69]. Abscisic acid is considered the root-to-shoot stress signal and its increased concentration in the xylem was found to be correlated with reduced leaf conductance and general limitation of leaf growth. Since gibberellins stimulate the catabolism of ABA [70], the exogenous application of gibberellic acid might limit the ABA-mediated negative response of plants to salinity. Moreover, $\mathrm{GA}_{3}$ has been shown to have many positive direct effects on plant metabolism and plant growth $[24,28,31,62]$. Plants supplemented with exogenous $\mathrm{GA}_{3}$ have shown enhanced activity of carbonic anhydrase (CA), which plays a role in $\mathrm{CO}_{2}$ fixation in the chloroplast during photosynthesis [44]. This increased enzymatic activity may improve the $\mathrm{CO}_{2}$ supply at the site of its fixation and increases the net photosynthetic rate, thus increasing biomass accumulation and yield [44,71]. Another contribution that could have increased the photosynthetic rate of lettuce and rocket plants could be ascribed to the positive effect of $\mathrm{GA}_{3}$ on stomatal conductance. This effect was found in the unstressed plants of both leafy vegetables, and even in salt stress conditions in lettuce plants as also found in tomato grown in soilless cultivation at low salinity [18]. Plants grown under salt stress try to compensate for the reduced ability to take up water with stomatal closure, which reduces the volume of air exchanged with the environment. This mechanism can be an efficient system to have more economical water utilization and may limit the harmful salt ions' uptake [72]. Nonetheless, the reduction in stomatal conductance and the low intercellular $\mathrm{CO}_{2}$ led to lower photosynthetic rates and limited growth [73], hence the positive effects of $\mathrm{GA}_{3}$ on stomatal opening and photosynthetic rates resulted in enhanced water use efficiency and consequently in improved nitrogen use efficiency even if to a different extent for the leafy vegetable tested.

As well as stomatal closure, salt stress affects the rate at which plants produce new leaves and influences other leaf characteristics that may determine a negative impact on photosynthesis and plant growth, such as leaf number and leaf expansion and mesophyll anatomy [74,75]. These modifications may vary among species as they can cope with salt stress through different tolerance strategies. Leaf morphology changes were also found in this experiment for lettuce and rocket floating on MNS with high EC. In fact, a reduction in the total leaf area per plant was recorded for both species and was due to variation of the leaf morphology (leaf width in lettuce and petiole length in rocket), leaf area, and leaf number per plant. Moreover, salt-stressed lettuce leaves were thicker than control leaves as shown by the lower SLA. Leaf thickening may negatively influence the diffusion of $\mathrm{CO}_{2}$ in the mesophyll and this parameter may have a role in limiting the photosynthesis of stressed leaves [75]. The differences determined by salt stress in SLA between lettuce and rocket could be due to differences in the mechanisms that species activate to overcome salt stress. $\mathrm{GA}_{3}$ supplementation helped salt-stressed 
plants in limiting the negative effect of salt stress on leaf development and morphology and confirmed an improvement of these characteristics in control plants [24]. The application of $\mathrm{GA}_{3}$ is often simultaneous with an increase in stomatal conductance and a decrease in intercellular $\mathrm{CO}_{2}$ partial pressure, which increases the net photosynthetic rate [45]. The positive effect of $\mathrm{GA}_{3}$ against salt stress could be ascribed to the morphological modifications that it determined in lettuce and rocket plants. These effects of $\mathrm{GA}_{3}$ supplementation could be very beneficial on leafy vegetables grown in hydroponic floating systems under salt stress, where a high plant density slows air movement inside the canopy, thus negatively affecting $\mathrm{CO}_{2}$ availability. Moreover, leafy vegetable quality is mostly based on leaf appearance, and the modifications induced by salt stress can negatively influence their market value. In addition to leaf size and morphology, salt stress may also affect leaf color as it can influence chlorophyll synthesis and degradation. Chlorophyll content may be lowered by increasing salinity, but this variation could depend on plant sensitivity or tolerance to salt stress. Leaf lettuce and rocket differed slightly in color changes due to $\mathrm{NaCl}$, thus confirming the differences in species response. Generally, salt stress lowered color lightness and chroma and increased the hue angle, but these variations were very small in both species so that the variation in the photosynthetic pigment content was probably also small. Besides, the increase in leaf thickness recorded in salt-stressed lettuce plants could have determined a chlorophyll accumulation per unit leaf area [76] that could explain the increase of the hue angle under salt stress conditions.

Even if lettuce and rocket had a similar response to salt stress and $\mathrm{GA}_{3}$ treatment as regards plant growth and morphology, the experimental factors determined changes in the metabolism that differed in the tested species, as suggested by the differences in SSC, TA, ascorbic acid, and nitrate content. The presence of these chemical components could be modified in response to salt stress. In fact, many plants react to salinity by activating or improving some metabolic pathways or the biosynthesis of secondary metabolites; among these, soluble solids, sugars, organic acids, proteins, and amino acids may play a role in plant turgor maintenance, acting as osmolytes or osmoregulators [48,77]. These metabolites are often responsible for the nutritive quality of fruits and vegetables, thus their presence could enhance the market value of the products, offsetting the economic losses caused by yield reductions due to salinity $[48,78]$. The increase of SSC in salt-stressed lettuce leaves confirmed that this species reacted as others by accumulating soluble carbohydrates in response to salinity $[78,79]$. The increase of soluble solids in rocket leaves was very low, thus indicating that rocket plants activated other mechanisms to reduce their osmotic potential and to maintain plant turgor. Moreover, $\mathrm{GA}_{3}$ treatment determined a significant decrease of SSC in rocket plants irrespective of salt stress that could be due to increased growth promoted by the exogenous supply of $\mathrm{GA}_{3}$, which increased carbohydrate utilization.

Plants react to the increase of reactive oxygen species under salt stress by activating certain antioxidative enzymes (catalase, peroxidase, glutathione reductase, and superoxide dismutase) and the scavenging of free radicals could also cause a decrease in total ascorbate, total glutathione, and $\alpha$-tocopherol levels $[80,81]$. Leaf lettuce and rocket showed a reduction of the ascorbic acid content in salt-stressed plants that was probably caused by the counteracting of reactive oxygen species. $\mathrm{GA}_{3}$ treatment acted with an opposite trend on the ascorbic acid content of lettuce and rocket, showing again that the contribution of gibberellic acid in counteracting salt stress could involve different mechanisms in different species. Moreover, ascorbic acid accumulation could strictly depend on nitrogen availability and translocation, thus the different responses of the ascorbic acid content to the $\mathrm{GA}_{3}$ treatment could be related to the differences in the nitrogen metabolism of lettuce and rocket plants determined by $\mathrm{GA}_{3}$ supplementation as revealed by the differing nitrate accumulation. High availability of nitrogen seems to be related to a lower concentration of vitamin $C$ in some fruits and vegetables, with variations that could depend on species, climate, and other factors $[82,83]$. This was confirmed in this work as the level of ascorbic acid was negatively related to the nitrate content of the leaves.

As already stated, the salinity of soil solution or irrigation water can determine imbalances in nutrient uptake, making the absorption of essential cations and anions, such as $\mathrm{K}^{+}$and $\mathrm{NO}_{3}{ }^{-}$, problematic to plants $[84,85]$. Leafy vegetables may accumulate a great amount of nitrates in the leaves, 
causing a reduction of their nutritional quality as nitrates can be harmful to human health [86-88]. Furthermore, if the nitrate content of lettuce and rocket overcomes the thresholds imposed by EU regulations, they can even lose marketability [89]. Salt stress can determine a reduction of nitrate reductase activity in some species, leading to nitrate accumulation [90]. Nevertheless, the reduction of nitrate uptake caused by moderate salinity could help in improving the nutritional quality and economic value of some leafy vegetables. This goal was obtained in rocket plants grown with 20 $\mathrm{mM} \mathrm{NaCl}$ in the MNS whereas salt stress did not affect the nitrate content of lettuce, showing that the root system of these species could differ in uptake capacity. Differences were also found in their response to $\mathrm{GA}_{3}$ treatments as regards the nitrate content of the leaves as also found in previous works $[24,32]$. As already discussed, $\mathrm{GA}_{3}$ positively affected NUE and this may be due to the effect of gibberellic acid on improving nitrogen utilization by enhancing $\mathrm{N}$ metabolism and its redistribution in the plants [31]. The exogenous $\mathrm{GA}_{3}$ supplementation stimulated plant growth, thus increasing the needs of nitrogen for tissue development. It is known that $\mathrm{GA}_{3}$ has a role in regulating the distribution of the assimilates from the photosynthetic tissue to the shoot apex and the young leaves, aiding in the utilization of nitrogen and thus increasing plant biomass and yield [31]. Gibberellins can also influence the activity of nitrate reductase, an enzyme that is crucial for the nitrogen metabolism of plants [91,92]. The positive effect of $\mathrm{GA}_{3}$ on nitrate reductase of rocket plants could have determined a reduction of nitrate accumulation even under salt stress. On the contrary, lettuce plants supplied with $\mathrm{GA}_{3}$ could have increased the nitrate content during growth thanks to a more efficient translocation from roots to leaves where nitrate competed with sodium ions for accumulation in the vacuoles, alleviating ionic and osmotic stress and maintaining plant turgor [9].

The severity of salinity effects may vary greatly according to species or even to varieties within a species and it may be moderated or accentuated by environmental or agronomic factors [47]. These differences and the modification to salt tolerance were shown well by the PCA analysis that underlined the different responses of lettuce and rocket to salt stress and showed that the supply of exogenous $\mathrm{GA}_{3}$ counterbalanced the salinity, acting on different plant adaptation systems. Moreover, the effects of $\mathrm{GA}_{3}$ treatment had a different extent in the tested species, thus confirming that the response to exogenous $\mathrm{GA}_{3}$ may vary according to species $[24,32,93]$.

\section{Conclusions}

Leaf lettuce and rocket plants floating on mineral nutrient solutions with an increasing level of $\mathrm{NaCl}$ suffered a significant reduction of growth and yield, determined by a reduction of the leaf number and leaf area, even with moderate salt stress $(10 \mathrm{mM} \mathrm{NaCl})$. The supplementation of exogenous $\mathrm{GA}_{3}$ through the MNS allowed substantial counterbalancing of the salt stress by enhancing various morphological and physiological traits, such as biomass accumulation, leaf expansion, stomatal conductance, WUE, NUE, etc. The effects of salt stress and $\mathrm{GA}_{3}$ treatment varied according to the species as also shown by the contrasting response in nitrate and soluble solid accumulation. This showed that $\mathrm{GA}_{3}$ may improve salt tolerance by activating different adaptation systems. The supplementation of $10^{-6} \mathrm{M} \mathrm{GA}_{3}$ through the nutrient solution is recommended for hydroponic cultivation of leaf lettuce and rocket when difficulties in finding water of good quality leads to the compelling necessity of identifying sustainable ways to use saline water (up to $20 \mathrm{mM} \mathrm{NaCl}$ ), as it can limit their negative effect on crop yield and quality.

Author Contributions: Conceptualization, F.V., A.M. (Alessandra Moncada) and A.M. (Alessandro Miceli); Data curation, F.V., A.M. (Alessandra Moncada) and A.M. (Alessandro Miceli); Formal analysis, A.M. (Alessandra Moncada) and A.M. (Alessandro Miceli); Investigation, F.V., A.M. (Alessandra Moncada) and A.M. (Alessandro Miceli); Methodology, F.V. and A.M. (Alessandro Miceli); Supervision, F.V. and A.M. (Alessandro Miceli); Validation, F.V., A.M. (Alessandra Moncada) and A.M. (Alessandro Miceli); Writing-original draft, A.M. (Alessandro Miceli); Writing-review \& editing, F.V., A.M. (Alessandra Moncada) and A.M. (Alessandro Miceli). All authors have read and agreed to the published version of the manuscript.

Funding: This research received no external funding.

Conflicts of Interest: The authors declare no conflict of interest. 


\section{References}

1. Shahbaz, M.; Ashraf, M. Improving Salinity Tolerance in Cereals. Crit. Rev. Plant Sci. 2013, 32, $237-249$. [CrossRef]

2. Yamaguchi, T.; Blumwald, E. Developing salt-tolerant crop plants: Challenges and opportunities. Trends Plant Sci. 2005, 10, 615-620. [CrossRef]

3. Sudhir, P.; Murthy, S.D.S. Effects of salt stress on basic processes of photosynthesis. Photosynthetica 2004, 42, 481-486. [CrossRef]

4. Marschner, H. Marschner's Mineral Nutrition of Higher Plants; Academic Press: Cambridge, MA, USA, 2011; ISBN 0123849063.

5. Iturbe-Ormaetxe, I.; Escuredo, P.R.; Arrese-Igor, C.; Becana, M. Oxidative damage in pea plants exposed to water deficit or paraquat. Plant Physiol. 1998, 116, 173-181. [CrossRef]

6. Gupta, N.K.; Meena, S.K.; Gupta, S.; Khandelwal, S.K. Gas exchange, membrane permeability, and ion uptake in two species of Indian jujube differing in salt tolerance. Photosynthetica 2002, 40, 535-539. [CrossRef]

7. Khan, N.A. NaCl-inhibited chlorophyll synthesis and associated changes in ethylene evolution and antioxidative enzyme activities in wheat. Biol. Plant. 2003, 47, 437-440. [CrossRef]

8. Munns, R. Comparative physiology of salt and water stress. Plant. Cell Environ. 2002, 25, 239-250. [CrossRef] [PubMed]

9. Mariani, L.; Ferrante, A. Agronomic management for enhancing plant tolerance to abiotic stresses-Drought, salinity, hypoxia, and lodging. Horticulturae 2017, 3, 52. [CrossRef]

10. Miceli, A.; Moncada, A.; D'Anna, F. Effect of salt stress in lettuce cultivation. Acta Hortic. 2003, 609, 371-375. [CrossRef]

11. Moncada, A.; Miceli, A.; D'Anna, F. Evaluation of strawberry cultivars in soilless cultivation in sicily. Acta Hortic. 2008, 801, 1121-1127. [CrossRef]

12. Settanni, L.; Miceli, A.; Francesca, N.; Cruciata, M.; Moschetti, G. Microbiological investigation of Raphanus sativus L. grown hydroponically in nutrient solutions contaminated with spoilage and pathogenic bacteria. Int. J. Food Microbiol. 2013, 160, 344-352. [CrossRef] [PubMed]

13. Moncada, A.; Miceli, A.; Sabatino, L.; Iapichino, G.; D'Anna, F.; Vetrano, F. Effect of molybdenum rate on yield and quality of lettuce, escarole, and curly endive grown in a floating system. Agronomy 2018, 8, 171. [CrossRef]

14. D'Anna, F.; Miceli, A.; Vetrano, F. First results of floating system cultivation of Eruca sativa L. Acta Hortic. 2003, 609, 361-364. [CrossRef]

15. Miceli, A.; Moncada, A.; Vetrano, F.; D'Anna, F. First results on yield and quality response of Basil (Ocimum basilicum L.) grown in a floating system. Acta Hortic. 2003, 609, 377-381. [CrossRef]

16. DAJIC,Z. Salt stress. In Physiology and Molecular Biology of Stress Tolerance in Plants; Springer: Berlin/Heidelberg, Germany, 2006; pp. 41-99.

17. Munns, R.; Tester, M. Mechanisms of salinity tolerance. Annu. Rev. Plant Biol. 2008, 59, 651-681. [CrossRef]

18. Maggio, A.; Barbieri, G.; Raimondi, G.; de Pascale, S. Contrasting Effects of GA 3 Treatments on Tomato Plants Exposed to Increasing Salinity. J. Plant Growth Regul. 2010, 29, 63-72. [CrossRef]

19. Wang, Y.; Mopper, S.; Hasenstein, K.H. Effects of salinity on endogenous ABA, IAA, JA, and SA in Iris hexagona. J. Chem. Ecol. 2001, 27, 327-342. [CrossRef]

20. Egamberdieva, D. Alleviation of salt stress by plant growth regulators and IAA producing bacteria in wheat. Acta Physiol. Plant. 2009, 31, 861-864. [CrossRef]

21. Khan, M.A.; Gul, B.; Weber, D.J. Action of plant growth regulators and salinity on seed germination of Ceratoides lanata. Can. J. Bot. 2004, 82, 37-42. [CrossRef]

22. Afzal, I.; Basra, S.A.; Iqbal, A. The effects of seed soaking with plant growth regulators on seedling vigor of wheat under salinity stress. J. Stress Physiol. Biochem. 2005, 1, 6-14.

23. Hooley, R. Gibberellins: Perception, transduction and responses. In Signals and Signal Transduction Pathways in Plants; Springer: Berlin/Heidelberg, Germany, 1994; pp. 293-319.

24. Miceli, A.; Moncada, A.; Sabatino, L.; Vetrano, F. Effect of Gibberellic Acid on Growth, Yield, and Quality of Leaf Lettuce and Rocket Grown in a Floating System. Agronomy 2019, 9, 382. [CrossRef]

25. Sun, T. Gibberellin signal transduction in stem elongation \& leaf growth. In Plant Hormones; Springer: Berlin/Heidelberg, Germany, 2010; pp. 308-328. 
26. KHAN, M.M.A.; Gautam, C.; Mohammad, F.; Siddiqui, M.H.; Naeem, M.; Khan, M.N. Effect of gibberellic acid spray on performance of tomato. Turk. J. Biol. 2006, 30, 11-16.

27. Khan, N.A.; Ansari, H.R. Effect of gibberellic acid spray during ontogeny of mustard on growth, nutrient uptake and yield characteristics. J. Agron. Crop Sci. 1998, 181, 61-63. [CrossRef]

28. Pal, P.; Yadav, K.; Kumar, K.; Singh, N. Effect of gibberellic acid and potassium foliar sprays on productivity and physiological and biochemical parameters of parthenocarpic cucumber cv.'Seven Star F1'. J. Hortic. Res. 2016, 24, 93-100. [CrossRef]

29. Shah, S.H. Effects of Salt Stress on Mustard As Affected By Gibberellic Acid Application. Gen. Appl. Plant Physiol. 2007, 33, 97-106.

30. Gelmesa, D.; Abebie, B.; Desalegn, L. Effects of gibberellic acid and 2,4-dichlorophenoxyacetic acid spray on fruit yield and quality of tomato (Lycopersicon esculentum Mill.). J. Plant Breed. Crop Sci. 2010, 2, 316-324.

31. Khan, N.A.; Mir, R.; Khan, M.; Javid, S. Effects of gibberellic acid spray on nitrogen yield efficiency of mustard grown with different nitrogen levels. Plant Growth Regul. 2002, 38, 243-247. [CrossRef]

32. Miceli, A.; Vetrano, F.; Sabatino, L.; D'Anna, F.; Moncada, A. Influence of preharvest gibberellic acid treatments on postharvest quality of minimally processed leaf lettuce and rocket. Horticulturae 2019, 5, 63. [CrossRef]

33. Sonneveld, C.; Voogt, W. Plant Nutrition of Greenhouse Crops; Springer: Berlin/Heidelberg, Germany, 2009; ISBN 9789048125326.

34. Goto, E.; Both, A.-J.; Albright, L.D.; Langhans, R.W.; Leed, A.R. Effect of dissolved oxygen concentration on lettuce growth in floating hydroponics. In Proceedings of the International Symposium on Plant Production in Closed Ecosystems, Narita, Japan, 26-29 August 1996; pp. 205-210.

35. Fageria, N.K.; Baligar, V.C.; Li, Y.C. The role of nutrient efficient plants in improving crop yields in the twenty first century. J. Plant Nutr. 2008, 31, 1121-1157. [CrossRef]

36. McGuire, R.G. Reporting of objective color measurements. HortScience 1992, 27, 1254-1255. [CrossRef]

37. Magwaza, L.S.; Opara, U.L. Analytical methods for determination of sugars and sweetness of horticultural products-A review. Sci. Hortic. 2015, 184, 179-192. [CrossRef]

38. Sadler, G.D.; Murphy, P.A. pH and Titratable Acidity. In Food Analysis; Springer: Boston, MA, USA, 2010; pp. 219-238.

39. Rodrigo, M.C.; Ramos, C. Nitrate sap analysis as a tool to assess nitrogen nutrition in artichoke. In Proceedings of the VI International Symposium on Artichoke, Cardoon and Their Wild Relatives, Lorca, Spain, 28-31 March 2006; pp. 251-256.

40. Miceli, A.; Miceli, C. Effect of nitrogen fertilization on the quality of swiss chard at harvest and during storage as minimally processed produce. J. Food Qual. 2014, 37, 125-134. [CrossRef]

41. Caracciolo, G.; D'Anna, E.; Moncada, A.; D'Anna, F. Evaluation of the quality and antioxidant capacity of woodland strawberry biotypes in Sicily. J. Food Agric. Environ. 2013, 11, 522-525.

42. Tuna, A.L.; Kaya, C.; Dikilitas, M.; Higgs, D. The combined effects of gibberellic acid and salinity on some antioxidant enzyme activities, plant growth parameters and nutritional status in maize plants. Environ. Exp. Bot. 2008, 62, 1-9. [CrossRef]

43. Munns, R.; James, R.A.; Läuchli, A. Approaches to increasing the salt tolerance of wheat and other cereals. J. Exp. Bot. 2006, 57, 1025-1043. [CrossRef]

44. Khan, N.A. Effect of gibberellic acid on carbonic anhydrase, photosynthesis, growth and yield of mustard. Biol. Plant. 1996, 38, 145. [CrossRef]

45. Yuan, L.; Xu, D.-Q. Stimulation effect of gibberellic acid short-term treatment on leaf photosynthesis related to the increase in Rubisco content in broad bean and soybean. Photosynth. Res. 2001, 68, 39-47. [CrossRef]

46. Shahbaz, M.; Ashraf, M.; Al-Qurainy, F.; Harris, P.J.C. Salt Tolerance in Selected Vegetable Crops. Crit. Rev. Plant Sci. 2012, 31, 303-320. [CrossRef]

47. Shannon, M.C.; Grieve, C.M. Tolerance of vegetable crops to salinity. Sci. Hortic. 1998, 78, 5-38. [CrossRef]

48. Grieve, C.M.; Grattan, S.R.; Maas, E.V. Plant salt tolerance. Agric. Salin. Assess. Manag. 2012, 2, $405-459$.

49. Shalhevet, J. Plants under salt and water stress. In Plant Adaptation to Environmental Stress; Fowden, L., Mansfield, T., Stoddart, J., Eds.; Chapman and Hall: London, UK, 1993; p. 133.

50. Srivastava, J.P.; Gupta, S.C.; Lal, P.; Muralia, R.N.; Kumar, A. Effect of Salt Stress on Physiological and Biochemical Parameters of Wheat. Annu. Arid Zone 1988, 27, 197-204. 
51. Javid, M.G.; Sorooshzadeh, A.; Moradi, F.; Ali, S.; Modarres, M. Review article The role of phytohormones in alleviating salt stress in crop plants. Annu. Rev. Plant Biol. 2011, 5, 726-734.

52. Shah, S.H.; Ahmad, I. Effect of gibberellic acid spray on growth, nutrient uptake and yield attributes during various growth stages of black cumin (Nigella sativa L.). Asian J. Plant Sci. 2006, 5, 881-884.

53. Aldesuquy, H.S.; Ibrahim, A.H. Interactive effect of seawater and growth bioregulators on water relations, abscisic acid concentration and yield of wheat plants. J. Agron. Crop Sci. 2001, 187, 185-193. [CrossRef]

54. Evins, W.H.; Varner, J.E. Hormonal control of polyribosome formation in barley aleurone layers. Plant Physiol. 1972, 49, 348-352. [CrossRef]

55. Broughton, W.J.; McComb, A.J. Changes in the pattern of enzyme development in gibberellin-treated pea internodes. Ann. Bot. 1971, 35, 213-228. [CrossRef]

56. Johri, M.; Varner, J.E. Enhancement of RNA synthesis in isolated pea nuclei by gibberellic acid. Proc. Natl. Acad. Sci. USA 1968, 59, 269. [CrossRef]

57. ROTH-BEJERANO, N.; Lips, S.H. Hormonal regulation of nitrate reductase activity in leaves. New Phytol. 1970, 69, 165-169. [CrossRef]

58. Al-Wakeel, S.A.M.; Dadoura, S.S.; Hamed, A.A. Interactive effects of water stress and gibberellic acid on mineral composition of fenugreek plant. Egypt. J. Rhysiol. Sci. 1994, 18, 269-282.

59. Ansari, H. Effect of Some Phytohormones and NPK on Growth and Metabolism of Mustard. Ph.D. Thesis, Aligarh Muslim University, Aligarh, India, 1996.

60. Daie, J.; Watts, M.; Aloni, B.; Wyse, R.E. In vitro and in vivo modification of sugar transport and translocation in celery by phytohormones. Plant Sci. 1986, 46, 35-41. [CrossRef]

61. Estruch, J.J.; Peretó, J.G.; Vercher, Y.; Beltrán, J.P. Sucrose loading in isolated veins of Pisum sativum: Regulation by abscisic acid, gibberellic acid, and cell turgor. Plant Physiol. 1989, 91, 259-265. [CrossRef] [PubMed]

62. Mulligan, D.R.; Patrick, J.W. Gibberellic-acid-promoted transport of assimilates in stems of Phaseolus vulgaris L. Planta 1979, 145, 233-238. [CrossRef] [PubMed]

63. Wood, A.; Paleg, L.G. The influence of gibberellic acid on the permeability of model membrane systems. Plant Physiol. 1972, 50, 103-108. [CrossRef]

64. Wood, A.; Paleg, L.G. Alteration of liposomal membrane fluidity by gibberellic acid. Funct. Plant Biol. 1974, 1, 31-40. [CrossRef]

65. Hniličková, H.; Hnilička, F.; Martinkova, J.; Kraus, K. Effects of salt stress on water status, photosynthesis and chlorophyll fluorescence of rocket. Plant Soil Environ. 2017, 63, 362-367.

66. Urlić, B.; Dumičić, G.; Romić, M.; Ban, S.G. The effect of $\mathrm{N}$ and $\mathrm{NaCl}$ on growth, yield, and nitrate content of salad rocket (Eruca sativa Mill.). J. Plant Nutr. 2017, 40, 2611-2618. [CrossRef]

67. Kim, H.J.; Fonseca, J.M.; Choi, J.H.; Kubota, C.; Dae, Y.K. Salt in irrigation water affects the nutritional and visual properties of romaine lettuce (Lactuca sativa L.). J. Agric. Food Chem. 2008, 56, 3772-3776. [CrossRef]

68. Al-Maskri, A.; Al-Kharusi, L.; Al-Miqbali, H.; Khan, M.M. Effects of salinity stress on growth of lettuce (Lactuca sativa) under closed-recycle nutrient film technique. Int. J. Agric. Biol. 2010, 12, 377-380.

69. Zhang, J.; Jia, W.; Yang, J.; Ismail, A.M. Role of ABA in integrating plant responses to drought and salt stresses. Field Crops Res. 2006, 97, 111-119. [CrossRef]

70. Gonai, T.; Kawahara, S.; Tougou, M.; Satoh, S.; Hashiba, T.; Hirai, N.; Kawaide, H.; Kamiya, Y.; Yoshioka, T. Abscisic acid in the thermoinhibition of lettuce seed germination and enhancement of its catabolism by gibberellin. J. Exp. Bot. 2004, 55, 111-118. [CrossRef]

71. Khan, N.A. Variation in carbonic anhydrase activity and its relationship with photosynthesis and dry mass of mustard. Photosynthetica 1994, 30, 317.

72. Stępień, P.; Kłbus, G. Water relations and photosynthesis in Cucumis sativus L. leaves under salt stress. Biol. Plant. 2006, 50, 610. [CrossRef]

73. Downton, W.J.S.; Grant, W.J.R.; Robinson, S.P. Photosynthetic and stomatal responses of spinach leaves to salt stress. Plant Physiol. 1985, 78, 85-88. [CrossRef] [PubMed]

74. Nawaz, K.; Hussain, K.; Majeed, A.; Khan, F.; Afghan, S.; Ali, K. Fatality of salt stress to plants: Morphological, physiological and biochemical aspects. Afr. J. Biotechnol. 2010, 9, 5475-5480.

75. Delfine, S.; Alvino, A.; Zacchini, M.; Loreto, F. Consequences of salt stress on conductance to $\mathrm{CO}_{2}$ diffusion, Rubisco characteristics and anatomy of spinach leaves. Funct. Plant Biol. 1998, 25, 395-402. [CrossRef] 
76. Lacerda, C.F.; Assis Júnior, J.O.; Lemos Filho, L.C.A.; de Oliveira, T.S.; Guimarães, F.V.A.; Gomes-Filho, E.; Prisco, J.T.; Bezerra, M.A. Morpho-physiological responses of cowpea leaves to salt stress. Braz. J. Plant Physiol. 2006, 18, 455-465. [CrossRef]

77. Ashraf, M.; Harris, P.J.C. Potential biochemical indicators of salinity tolerance in plants. Plant Sci. 2004, 166, 3-16. [CrossRef]

78. Mizrahi, Y.; Pasternak, D. Effect of salinity on quality of various agricultural crops. Plant Soil 1985, 89, 301-307. [CrossRef]

79. Parida, A.K.; Das, A.B. Salt tolerance and salinity effects on plants: A review. Ecotoxicol. Environ. Saf. 2005, 60, 324-349. [CrossRef]

80. Mittova, V.; Tal, M.; Volokita, M.; Guy, M. Salt stress induces up-regulation of an efficient chloroplast antioxidant system in the salt-tolerant wild tomato species Lycopersicon pennellii but not in the cultivated species. Physiol. Plant. 2002, 115, 393-400. [CrossRef]

81. Parvaiz, A.; Satyawati, S. Salt stress and phyto-biochemical responses of plants-A review. Plant Soil Environ. 2008, 54, 89. [CrossRef]

82. Lee, S.K.; Kader, A.A. Preharvest and postharvest factors influencing vitamin C content of horticultural crops. Postharvest Biol. Technol. 2000, 20, 207-220. [CrossRef]

83. Stefanelli, D.; Goodwin, I.; Jones, R. Minimal nitrogen and water use in horticulture: Effects on quality and content of selected nutrients. Food Res. Int. 2010, 43, 1833-1843. [CrossRef]

84. Cova, A.M.W.; De Freitas, F.T.O.; Viana, P.C.; Rafael, M.R.S.; De Azevedo Neto, A.D.; Soares, T.M. Content of inorganic solutes in lettuce grown with brackish water in different hydroponic systems. Rev. Bras. Eng. Agric. Ambient. 2017, 21, 150-155. [CrossRef]

85. Pérez-López, U.; Miranda-Apodaca, J.; Lacuesta, M.; Mena-Petite, A.; Muñoz-Rueda, A. Growth and nutritional quality improvement in two differently pigmented lettuce cultivars grown under elevated $\mathrm{CO}_{2}$ and/or salinity. Sci. Hortic. 2015, 195, 56-66. [CrossRef]

86. Miceli, A.; Gaglio, R.; Francesca, N.; Ciminata, A.; Moschetti, G.; Settanni, L. Evolution of shelf life parameters of ready-to-eat escarole (Cichorium endivia var. latifolium) subjected to different cutting operations. Sci. Hortic. 2019, 247, 175-183. [CrossRef]

87. Alfonzo, A.; Gaglio, R.; Miceli, A.; Francesca, N.; Di Gerlando, R.; Moschetti, G.; Settanni, L. Shelf life evaluation of fresh-cut red chicory subjected to different minimal processes. Food Microbiol. 2018, 73, 298-304. [CrossRef]

88. Miceli, C.; Moncada, A.; Vetrano, F.; Iapichino, G.; D'anna, F.; Miceli, A. Effect of agronomic practices on Yield and Quality of Borage at Harvest and during Storage as Minimally Processed Produce. Agronomy 2020, 10, 242. [CrossRef]

89. Union, E. Commission Regulation (EC) No. 1258/2011 of 2 December 2011 amending Regulation (EC) No. 1881/2006 as regards maximum levels for nitrates in foodstuffs. Off. J. Eur. Union 2011, 320, 15-17.

90. Gouia, H.; Ghorbal, M.H.; Touraine, B. Effects of $\mathrm{NaCl}$ on flows of $\mathrm{N}$ and mineral ions and on NO3- reduction rate within whole plants of salt-sensitive bean and salt-tolerant cotton. Plant Physiol. 1994, 105, 1409-1418. [CrossRef]

91. Zhang, M.; Liu, M.; Zhang, Y.; Ji, Y.; Zhao, M.; Wu, Z. Effect of different plant growth regulator added in nutrient solution on growth and development of summer tomato seedling. North Hortic 2017, 6, 8-13.

92. Chanda, S.V.; Sood, C.R.; Reddy, V.S.; Singh, Y.D. Influence of plant growth regulators on some enzymes of nitrogen assimilation in mustard seedlings. J. Plant Nutr. 1998, 21, 1765-1777. [CrossRef]

93. Cleland, R.E. Chapter 1 Introduction: Nature, occurrence and functioning of plant hormones. In Biochemistry and Molecular Biology of Plant Hormones; Hooykaas, P.J.J., Hall, M.A., Libbenga, K.R., Eds.; Elsevier: Amsterdam, The Netherlands, 1999; Volume 33, pp. 3-22.

(C) 2020 by the authors. Licensee MDPI, Basel, Switzerland. This article is an open access article distributed under the terms and conditions of the Creative Commons Attribution (CC BY) license (http://creativecommons.org/licenses/by/4.0/). 